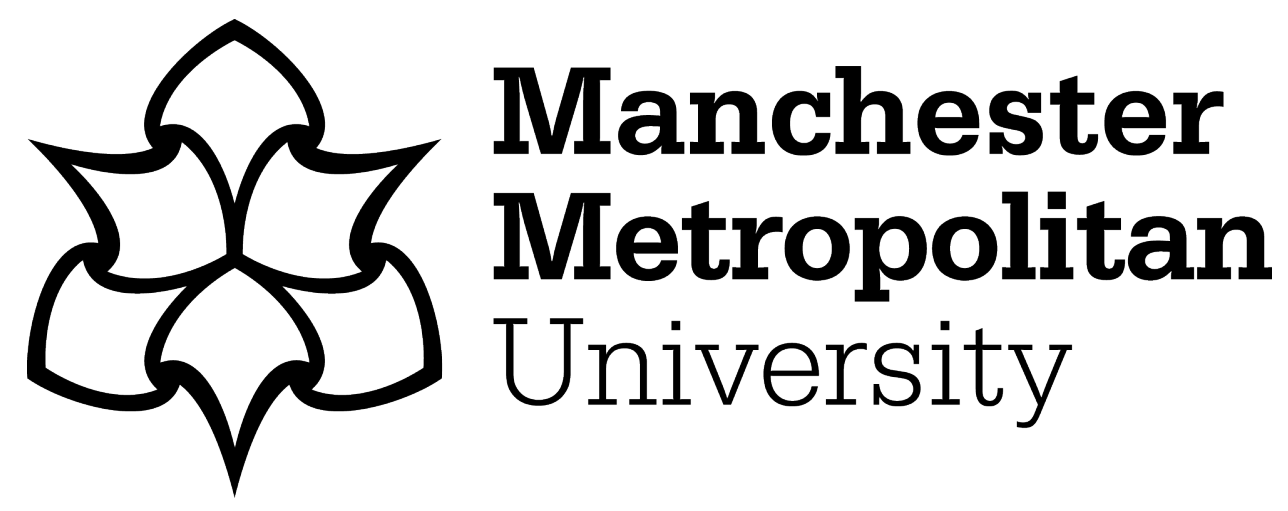

Kamaruzzaman, Syahrul Nizam, Lou, Eric, Wong, Phui Fung, Edwards, Rodger, Hamzah, Noraini and Ghani, Mohd Khairolden (2018) Development of a non-domestic building refurbishment scheme for Malaysia: A Delphi approach. Energy, 167. pp. 804-818. ISSN 0360-5442

Downloaded from: https://e-space.mmu.ac.uk/621890/

Version: Accepted Version

Publisher: Elsevier

DOI: https://doi.org/10.1016/j.energy.2018.11.020

Usage rights: Creative Commons: Attribution-Noncommercial-No Derivative Works 4.0

Please cite the published version 


\title{
Development of a non-domestic building refurbishment scheme for Malaysia:
}

\section{A Delphi Approach}

\author{
Syahrul Nizam Kamaruzzaman ${ }^{1}$, Eric Choen Weng Lou ${ }^{2}$, Phui Fung Wong ${ }^{3 *}$, Rodger Edwards ${ }^{4}$, \\ Noraini Hamzah ${ }^{5}$, Mohd Khairolden Ghani ${ }^{6}$ \\ ${ }^{1}$ Faculty of Built Environment, University of Malaya, 50603 Kuala Lumpur, Malaysia \\ 2, School of Engineering, John Dalton Building, Manchester Metropolitan University, M15 6BH United Kingdom. \\ ${ }^{3}$ Department of Surveying, Lee Kong Chian Faculty of Engineering and Science, Universiti Tunku Abdul Rahman (UTAR), Sungai Long \\ Campus, 43000 Kajang Malaysia \\ ${ }^{4}$ School of Mechanical, Aerospace and Civil Engineering, University of Manchester, Manchester M13 9PL, United Kingdom \\ ${ }^{5}$ Department of Civil and Structural Engineering, University Kebangsaan Malaysia, Bangi, Selangor, Malaysia \\ ${ }^{6}$ Construction Research Institute of Malaysia (CREAM), IBS Centre, $1{ }^{\text {st }}$ Floor, Block E, Lot 8, Jalan Chan Sow Lin, 55200 Kuala Lumpur, \\ Malaysia
}

\begin{abstract}
Building refurbishment is a key activity in achieving environmentally sustainable developments due to its potential for reducing greenhouse gas emissions and energy consumption associated with existing buildings. However, the general metrics for assessing the impacts of refurbishment have not been established for existing buildings in most countries. In Malaysia, there is currently no single environmental assessment scheme for building refurbishment. The existing environmental assessment schemes are not sufficiently robust, as they do not include factors such as quality of services and economic factors. It is essential to have a customised suite of sustainability assessment schemes specifically designed for the Malaysian context to facilitate best practice for non-domestic refurbishment assessment.

A comprehensive Delphi process was developed to assist in the identification of suitable assessment schemes for use in non-domestic buildings. Three successive rounds of surveys were conducted with ten Delphi experts with expertise in sustainability and green assessment. The study revealed that energy related factors were ranked as the most important assessment theme for refurbishment, followed by indoor environmental quality and water assessment. The findings of this research will be used to develop a weighting system by using the analytic hierarchy process in the next research stage, leading to a complete refurbishment environmental assessment scheme.
\end{abstract}

\footnotetext{
* Corresponding author. E-mail address: pfwong@utar.edu.my
} 
Keywords: assessment scheme; Delphi; energy; non-domestic buildings; refurbishment; sustainability.

\section{Introduction}

The impact of climate change has focused the attention of all nations on the development and implementation of strategies for improving sustainability within the built environment. Buildings have been the subject of much research and regulatory attention as they represent one of the largest sectors contributing to energy consumption $[1,2]$. The construction sector typically accounts for between onequarter and one-third of all energy use depending on the nation in question, and a similar proportion of greenhouse gas emissions [68]. It is anticipated that this contribution will increase due to population growth, increased cooling loads due to climate change, demand for greater comfort in buildings as more time is spent inside, and resultant increasing pressure for energy intensive building services such as air conditioning [6]. Improved energy efficiency in buildings is a vital objective, due to the savings that could be achieved in terms of energy and carbon dioxide emissions throughout building lifecycles. Energy performance standards for new buildings are being progressively improved, and these improvements will offset the anticipated increases.

Existing buildings offer a greater potential in reducing energy consumption and greenhouse gas emissions through refurbishment to improve sustainability [7]. This is due to existing buildings being built according to the regulatory requirements and equipment (for example air condition and lighting) in place at the time of their construction. Upgrading of whole buildings to comply with modern standards is likely to be problematic in many situations, but actions in respect of equipment could lead to major improvements in energy performance with relatively little technical difficulty, but at a cost.

Environmental assessment schemes have emerged as a yardstick to measure and promote sustainability in the built environment [8]. In some cases, their usage forms part of the overall evidence base for demonstrating regulatory compliance. Their adoption serves an important role in promoting awareness of sustainable building practice [9]. Cole [10] explains that assessment schemes acts as tools to evaluate a building's impact on the ecosystem, which will inform the decision makers throughout the design process in order to achieve green building performance. The use of assessment schemes should play a role in a country's sustainable development plans and policies.

Various assessment schemes are used in different countries to achieve sustainable development. They can be mainly classified as schemes for use with new buildings, existing buildings and refurbished buildings assessment schemes. Assessment schemes, which cover both new and existing buildings, are common. In the United Kingdom in 2015, the Building Research Establishment Environmental Assessment Method (BREEAM) launched a separate tailored scheme for use in building refurbishment 
and fit-out [11]. In 2014, the Japan Green Building Council issued a version of Comprehensive Assessment System for Built Environment Efficiency (CASBEE) - refurbishment assessment tool for building refurbishment assessment to achieve sustainable performance for refurbished buildings (CASBEE Renovation) [12]. The Taiwanese Government launched the Ecology, Energy Saving, Waste Reduction and Health - Renovation (EEWH-RN) scheme in 2011 in order to facilitate the assessment of the sustainability performance of existing buildings upon refurbishment [13-14]. Other schemes do not have individual refurbishment variants, but instead use a new built scheme or scheme for existing buildings in order to evaluate refurbished buildings. These include the Leadership in Energy and Environmental Design (LEED) originated in the United States of America [15], the Building Environmental Assessment Method (BEAM Plus) in Hong Kong [16], Green Star in Australia [17], Haute Qualité Environnementale (HQE) in France [18], and Green Mark in Singapore [19].

In Malaysia, no specific assessment scheme for refurbishment projects has yet been introduced. The Green Building Index (GBI) was developed by the Malaysian Institute of Architects (PAM) and the Association of Consulting Engineers Malaysia (ACEM) released in 2010. Since then, it has been widely adopted [20]. GBI can be used for new construction and existing buildings, but the process used for the assessment of refurbishment is not sufficiently detailed. On the other hands, the public sector took the initiative in 2013 by introducing the Malaysian Carbon Reduction and Environmental Sustainability Tool (MyCrest), which aims to integrate socio-economic considerations into the built environment for carbon reduction [21]. MyCrest is applied to new and existing buildings. The overview of ten major assessment schemes from various counties for assessing refurbished buildings is displayed in Table 1. Specific and individual refurbishment schemes are highlighted in Table 1.

Analysing the well-known assessment schemes, it can be identified that the existing methods provide different ranking criteria to evaluate the performance of new and existing residential and nonresidential buildings. However, only BREEAM, CASBEE and GLBS have individual refurbishment assessment schemes for existing buildings and refurbishment purposes. Without refurbishment schemes, most of the existing rating tools will only use new and existing building assessment tools to evaluate refurbished buildings. Chang et al. [13] criticised the use of a single assessment evaluation for all building types whereas Li et al. [22] suggested that it is necessary to develop different assessment tools for different building types. This is due to many of the existing schemes include assessment criteria which are not closely associated with refurbished buildings. Moreover, the weighting factors used in most of the existing schemes prioritizes environmental problems, while economic and social issues are given less emphasis. Thus, it is important to find out the assessment themes and sub-themes for refurbished buildings, rather than using the assessment systems for new and existing buildings. As far back as 2009, Radhi [23] argued that an assessment tool for building refurbishment was urgently required. 
Various initiatives have been implemented and research carried out in different countries to develop suitable assessment tools, rating standards and certification system for evaluating buildings performance. This is due to the differences in geographical location, climatic conditions, environmental issue, cultural variation, and economic conditions [Shad et al. 2017]. In Saudi Arabia, Banani et al. (2016) proposed a framework for non-residential building assessment by comparing existing building assessment methods whereas Alyami et al. [40] developed a building assessment tools for residential buildings. An assessment tool was developed [Shad et al. 2017] in Iran by using a Geographic Information System (GIS) to integrate environmental, technical and economic aspects for green office buildings assessment. In Korea, Kang et al. [2016] presented the development process of a sustainable assessment tool for non-expert users at the decision making stage. In view of the fact that most of the existing assessment tools consisted of performance categories that are not closely related with sustainable building, Kang (2015) proposed a model for sustainable building assessment tools to facilitate decision-making for the realization of sustainable building during the design stage. Rather than focusing on buildings assessment from various assessment criteria, Yang et al. [43] determined a list of indicators for assessing energy efficiency in residential buildings in China. Malmqvist et al. [2011] described to the development of a Swedish building rating tool that covered three areas of assessment namely energy, indoor environmental and materials.

The findings of these studies resulted that developing standards could help in controlling energy consumption and reducing carbon emission by targeting on residential and non-residential buildings. Although these types of building have common characteristics but also have some different features. Reviewing existing literatures indicated that there was less existing research focused on refurbishment of existing buildings. Although these assessment tools have been developed by different authors from various countries, the existing policy and tools for building assessment lags behind the refurbished buildings. Therefore, they may not suitable to assess the refurbished buildings.

No refurbishment assessment tools has been developed that broadly considers Malaysia's specific climatic, societal and cultural issues. Thus, it is necessary to develop a refurbishment assessment tool to measure the performance of refurbished existing non-domestic buildings for making refurbishment practices more sustainable. This paper identifies applicable assessment themes and sub-themes for building refurbishment that in turn will be used to develop a refurbishment scheme for Malaysia. As highlighted by Banani et al. [2016], much attention has already been focused to residential buildings and more attention should be given to non-domestic buildings. In Malaysia, a fifth of total energy consumption is emitted by non-domestic buildings [24], hence the focus of this paper is upon this group of buildings.

Table 1 Overview of ten assessment schemes 


\begin{tabular}{|c|c|c|c|c|}
\hline Schemes & Country & $\begin{array}{l}\text { Year First } \\
\text { Published }\end{array}$ & Developer & $\begin{array}{l}\text { Assessment } \\
\text { Scheme }\end{array}$ \\
\hline $\begin{array}{l}\text { Building Research } \\
\text { Establishment } \\
\text { Environmental Assessment } \\
\text { Methodology (BREEAM) }\end{array}$ & UK & 1990 & $\begin{array}{l}\text { Building Research } \\
\text { Establishment }\end{array}$ & $\begin{array}{l}\text { BREEAM UK } \\
\text { Refurbishment } \\
\text { and Fit-out } 2015 *\end{array}$ \\
\hline $\begin{array}{l}\text { Leadership in Energy and } \\
\text { Environmental Design } \\
\text { (LEED) }\end{array}$ & USA & 1998 & $\begin{array}{l}\text { US Green Building } \\
\text { Council (GBC), CNU } \\
\text { (Congress for the new } \\
\text { urbanism), NRDC }\end{array}$ & $\begin{array}{l}\text { New construction } \\
\text { and major } \\
\text { renovations (v4) }\end{array}$ \\
\hline $\begin{array}{l}\text { Comprehensive } \\
\text { Assessment System for } \\
\text { Built Environment } \\
\text { Efficiency (CASBEE) }\end{array}$ & Japan & 2001 & $\begin{array}{l}\text { Japan Sustainable } \\
\text { Building Consortium } \\
\text { (JSBC), Japan Green } \\
\text { Building Council } \\
\text { (JaGBC) }\end{array}$ & $\begin{array}{l}\text { CASBEE- } \\
\text { Renovation * }\end{array}$ \\
\hline $\begin{array}{l}\text { Building Environmental } \\
\text { Assessment Method } \\
\text { (BEAM) Plus }\end{array}$ & $\begin{array}{l}\text { Hong } \\
\text { Kong }\end{array}$ & 1996 & $\begin{array}{l}\text { Hong Kong Green } \\
\text { Building Council }\end{array}$ & $\begin{array}{l}\text { New Building } \\
\text { Version } 1.2\end{array}$ \\
\hline $\begin{array}{l}\text { Green Building Labelling } \\
\text { System (GBLS) }\end{array}$ & Taiwan & 1999 & $\begin{array}{l}\text { Taiwan Architecture and } \\
\text { Building Research } \\
\text { Institute }\end{array}$ & $\begin{array}{l}\text { GBLS: EEWH- } \\
\text { Renovation * }\end{array}$ \\
\hline $\begin{array}{l}\text { Haute Qualité } \\
\text { Environnementale (HQE) }\end{array}$ & France & 1996 & HQE Association & $\begin{array}{l}\text { Environmental } \\
\text { performance non- } \\
\text { residential } \\
\text { buildings }\end{array}$ \\
\hline Green Star & Australia & 2003 & $\begin{array}{l}\text { Green Building Council } \\
\text { of Australia (GBCA) }\end{array}$ & $\begin{array}{l}\text { Design and as } \\
\text { Built }\end{array}$ \\
\hline Green Mark & Singapore & 2005 & $\begin{array}{l}\text { Building and } \\
\text { Construction Authority } \\
\text { (BCA) }\end{array}$ & $\begin{array}{l}\text { Non-residential } \\
\text { existing building }\end{array}$ \\
\hline $\begin{array}{l}\text { Green Building Index } \\
\text { (GBI) }\end{array}$ & Malaysia & 2010 & $\begin{array}{l}\text { Malaysian Institute of } \\
\text { Architects (PAM) and } \\
\text { the Association of } \\
\text { Consulting Engineers } \\
\text { Malaysia (ACEM) }\end{array}$ & $\begin{array}{l}\text { Non-residential } \\
\text { existing building }\end{array}$ \\
\hline $\begin{array}{l}\text { Malaysian Carbon } \\
\text { Reduction and } \\
\text { Environmental } \\
\text { Sustainability Tool } \\
\text { (MyCrest) }\end{array}$ & Malaysia & 2013 & $\begin{array}{l}\text { Public Work Department } \\
\text { (PWD) Malaysia and } \\
\text { Construction Industry } \\
\text { Development Board } \\
\text { (CIDB) }\end{array}$ & New Construction \\
\hline
\end{tabular}

Source: Kamaruzzaman et al. [25]

Note: * specific refurbishment scheme 


\section{Building refurbishment practice in Malaysia}

Building refurbishment has received increasing attention worldwide in recent years [26, 27] and the interest is spreading in Malaysia [28] due to its potentially significant effects in achieving improved building energy efficiency. Its practice is growing rapidly in the United Kingdom, where approximately 28 million buildings will need to be refurbished by the end of 2050 to meet the national carbon emission targets [29]. In the United States, the government has provided financial assistance to promote existing building refurbishment [30]. In Malaysia, the government has established a goal of refurbishing 100 government buildings between 2016 and 2020, as highlighted in the Eleventh Malaysia Plan [31].

Refurbishment is often defined as upgrading, repairing and carrying out the renovation, alteration, conversion, extension and modernisation of existing buildings [32]. Its increasing popularity is being driven by several factors, including the increasing number of old buildings, limited availability of new land for building, and technological changes [33]. Some existing buildings will become obsolete and outdated, which decreases their value and depreciation. Refurbishment provides a positive solution to physical deterioration and obsolescence, prolonging the building's lifecycle and securing the investment value of the property [34]. New land for development is becoming scarcer, which in turn promotes the refurbishment of existing buildings. Ali et al. [28] noted that there is a limited amount of strategic land available in Malaysia for new development and this land is only available at high prices, which makes new development less feasible. Mansfield [34] pointed out that a refurbishment project is often more economical than new development, involving less site work. There is a possibility that existing building components and materials can be reused and recycled. Technological changes mean that existing buildings accommodate a lot of obsolete systems and services that consume large amounts of energy, including electricity. Hence, the building owner is required to introduce modern, energy efficient systems and services during refurbishment in order to achieve improved energy efficiency [28].

In the absence of a plan for systematic demolition and replacement, the number of old buildings in a given stock increases with time. Refurbishment is often an attractive alternative to demolishing existing buildings. The environmental impact of the refurbishment process is almost invariably less than that of demolition, which generates large quantities of waste and dust, which cause pollution and noise. The waste generated requires proper treatment and disposal methods, such as appropriate sites for landfill. Hazardous materials such as asbestos may have to be dealt with. The transportation of waste from the demolition site to its disposal place itself creates carbon emissions and causes pollution. However, refurbishment should assist in achieving reductions in demolition waste [34].

Existing buildings offer a great opportunity for reducing energy consumption and thus making a significant contribution towards meeting the target [1,2]. Ahmed and Nayar [36] have claimed that 
existing buildings in Malaysia could reduce energy consumption by between 15 and $25 \%$ through the introduction of better energy efficiency practices. The Malaysian government has set a target of achieving an overall 45\% reduction in total carbon emissions by 2030 [37]. Refurbishment is now considered to be a key approach to achieving this target. At the same time, appropriate refurbishment can prolong the occupancy stage of the building lifecycle, improve thermal comfort, maintain a healthy working environment, and increase the value of the building [38].

\section{Research methodology}

This study is underpinned by this research question: what are the required assessment themes and sub-themes that are applicable to non-domestic buildings refurbishment within the Malaysian built environment? Pombo et al. [2] stressed that it is important to identify the assessment themes needed for assessing building refurbishment. In doing this, Cole [39] stated that a comparative study of prominent existing assessment schemes would be a sound starting point for such an identification process. A review of recent versions of relevant assessment schemes is crucial, as they evolve rapidly. This leads to the establishment of a comprehensive and up to date list of assessment themes and sub-themes.

In order to select applicable assessment themes and sub-themes, several methods could be used, including the Delphi approach, focus group discussions and traditional surveys. For instance, Alymai et al. [40] adopted a Delphi approach for developing a building assessment scheme for Saudi Arabia. The list of assessment themes was built upon the consensus of Delphi experts after three rounds of survey. Kang et al. [2016] also conducted Delphi surveys to rank the sustainability indicators for developing a three-layer assessment framework. The use of Delphi surveys is not limited to the built environment. For example, two focus group discussions were conducted by Dolom [41] to select the criteria and indictors of sustainability of community-based forest management for evaluating progress towards sustainable forest management. Ellison and Sayce [42] established a set of sustainability criteria that are relevant to the performance of commercial property by using focus group discussion. This enables market users to assess the sustainability of commercial property from various criteria such as building adaptability, waste management, water consumption, energy efficiency and etc. Yang et al. [43] conducted a questionnaire survey to identify the indicators for assessing the energy efficiency of residential buildings. A building energy efficiency assessment model were proposed that contribute to the establishment of energy assessment regulations.

Thus, different types of data collection methods have been adopted for identifying and selecting assessment criteria and indicators for use in assessment schemes. However, the Delphi approach was chosen after evaluation of the above-mentioned options (see Table 2) for this study for several reasons. As explained by Ding [9] , environmental building assessment themes are generally multi-dimensional 
and hence a consensus-based approach such as the Delphi approach is best suited for the development of an assessment scheme [44]. The Delphi approach is an iterative process as several rounds of questionnaires are conducted with a group of selected experts in the field, aiming to develop a result through consensus [45].

The selection of assessment themes requires the input of a stakeholder group whom understands both the assessment methods and refurbishment practices, whereas in a traditional survey, it may be that the respondents are not technically equipped to answer some or all of the questions appropriately. Hallowell and Gambatese [46] explained that Delphi stakeholder groups are selected based on predefined guidelines which are capable of providing useful insights into the research problems. Moreover, the participants in a Delphi based study should be anonymous and thus should not be not swayed by group dynamics and peer pressure, as can happen in focus group discussion. Experts engaged in the Delphi process should not interact with each other, reducing the risk of interpersonal conflict, communication problems and direct confrontation. Communication among focus group participants can distort the data and information developed from this data, thus introducing unintentional bias, which is not linked to the purpose of the study [46, 47].

It is easy to conduct an online survey with the Delphi expert group, who can answer the questionnaire from their own place of work, while a focus group requires effort and coordination to get all the experts in the same place and at the same time, or else teleconferencing / videoconferencing must be used, with all the attendant technical risks. The Delphi method solicits information from experts who have a wide range of experience and knowledge, permitting the collection of richer data, which allows for a deeper understanding of the research question [48]. It represents a group decision-making approach whereby the expert opinions about an issue are collected through iterative rounds of data collection to derive a consensus on the results. Hallowell and Gambatese, on the basis of its perceived advantages, [46] view Delphi as the preferred data collection method as compared to traditional surveys or focus groups. Hence, it would be appropriate to adopt the Delphi approach in this study as data collection method because the selection of assessment themes and sub-themes require a group of experts who have in-depth knowledge and experiences in the subject field (sustainability assessment and refurbishment). There are other studies adopting the Delphi approach in construction research. For instance, the contributory factors of accident causation were prioritised by Zahoor et al. [49] through a Delphi survey to identify the significant factors for reducing the occurrence of accidents in Pakistan construction industry. Alyami et al. [40] adopted the Delphi method for prioritise the assessment criteria in order to develop a framework of a building sustainability assessment scheme for use in Saudi Arabia. Chan et al. [52] conducted four rounds of Delphi surveys with ten panels to develop a procurement selection model based on a list of selection criteria. A Delphi survey was conducted by Vidal et al. [51] to examine different aspects of project complexity and used the results to propose a multi-criteria approach to project complexity evaluation. Chan et al [50] examined the safety and health-related problems 
encountered by ethnic minority construction workers in Hong Kong by using the Delphi approach to rank the construction safety and health-related problems. Various stakeholder groups were selected by $\mathrm{Li}$ et al. [53] to evaluate the level of influence of these groups on the sustainability of construction in China. The Delphi method was used to quantify the influence of diverse stakeholders in sustainability related project decision making processes. Ameyaw et al. [54] conducted a comprehensive review and concluded that the Delphi approach is a popular method to apply in construction, engineering and management research. 
Table 2: Comparison of traditional survey, Delphi approach and focus group discussion

\begin{tabular}{|c|c|c|c|}
\hline Characteristics & Traditional Survey & Delphi Approach & Focus Group Discussion \\
\hline Purpose & $\begin{array}{l}\text { A quantitative collection method that } \\
\text { consists of a set of questions used to } \\
\text { collect, analyse and interpret the } \\
\text { information from a selected group of } \\
\text { respondents. }\end{array}$ & $\begin{array}{l}\text { An iterative process that aims to attain } \\
\text { consensus of a group of experts by a series } \\
\text { of questionnaire surveys with controlled } \\
\text { feedback. }\end{array}$ & $\begin{array}{l}\text { A group of individuals selected and assembled } \\
\text { to discuss and gather information on a } \\
\text { particular topic, allowing group interaction to } \\
\text { gain better understanding of the topic. }\end{array}$ \\
\hline Procedure & $\begin{array}{l}\text { The researchers design a questionnaire } \\
\text { with questions that solicit quantitative } \\
\text { and qualitative data, and then distribute } \\
\text { it to a group of respondents. The } \\
\text { respondents complete the survey and } \\
\text { return it. The researchers analyse the } \\
\text { results and present the statistical } \\
\text { findings. }\end{array}$ & $\begin{array}{l}\text { The researchers design a questionnaire and } \\
\text { select a group of experts who are capable to } \\
\text { answer the research question. Then, they } \\
\text { distribute it to the group. They analyse the } \\
\text { results and design another survey based on } \\
\text { the results and then administer it. They } \\
\text { reiterate this process until a consensus on } \\
\text { the results is reached. }\end{array}$ & $\begin{array}{l}\text { The researchers invite and assemble a group of } \\
\text { people at a common time in a large space for } \\
\text { discussion. Associated equipment such as } \\
\text { audio or video taping facilities, visual aids and } \\
\text { writing material is needed. }\end{array}$ \\
\hline Population & $\begin{array}{l}\text { The researchers decide on the population } \\
\text { and select a random sample from it. The } \\
\text { results can be generalized to the } \\
\text { population. }\end{array}$ & $\begin{array}{l}\text { The results cannot be generalized to the } \\
\text { whole population. }\end{array}$ & The results cannot generalize to the population. \\
\hline Sample Size & $\begin{array}{l}\text { Because the result is generalized to a } \\
\text { large population, the researchers need to } \\
\text { choose a sufficiently large sample size. } \\
\text { The reliability of the analysis depends } \\
\text { on an appropriate sample size. }\end{array}$ & $\begin{array}{l}\text { The Delphi sample size is not a main } \\
\text { concern, but rather selection of a group of } \\
\text { experts for arriving at consensus. The } \\
\text { literature recommends at least } 10 \text { experts. }\end{array}$ & $\begin{array}{l}\text { The number of people per group is usually six } \\
\text { to ten. }\end{array}$ \\
\hline $\begin{array}{l}\text { Target } \\
\text { Respondents }\end{array}$ & $\begin{array}{l}\text { A target population that the researcher } \\
\text { wishes to investigate. }\end{array}$ & $\begin{array}{l}\text { Delphi expert refers to the individual who } \\
\text { possesses relevant knowledge, experience } \\
\text { and professional expertise in a particular } \\
\text { topic. }\end{array}$ & $\begin{array}{l}\text { A group of experts who possesses relevant } \\
\text { knowledge, experience and professional } \\
\text { expertise in a particular topic. }\end{array}$ \\
\hline
\end{tabular}




\begin{tabular}{|c|c|c|c|}
\hline Anonymity & $\begin{array}{l}\text { The respondents are anonymous to each } \\
\text { other and also to the researcher. }\end{array}$ & $\begin{array}{l}\text { The respondents are anonymous to each } \\
\text { other. }\end{array}$ & $\begin{array}{l}\text { The focus group participants are not } \\
\text { anonymous. }\end{array}$ \\
\hline Analysis & $\begin{array}{ll}\text { Statistical analysis } \\
\text { i. } & \text { Measures of central tendency } \\
& \text { (means, median, mode) and } \\
& \text { level of dispersion (standard } \\
& \text { deviation, variance) } \\
\text { ii. } & \text { Parametric and non-parametric } \\
& \text { test }\end{array}$ & $\begin{array}{l}\text { Statistical analysis } \\
\text { i. Measures of central tendency } \\
\text { (means, median, mode) and level of } \\
\text { dispersion (standard deviation, } \\
\text { variance) }\end{array}$ & $\begin{array}{l}\text { Qualitative analysis } \\
\text { i. } \quad \text { Coding system; manually or by } \\
\text { software. }\end{array}$ \\
\hline Strengths & 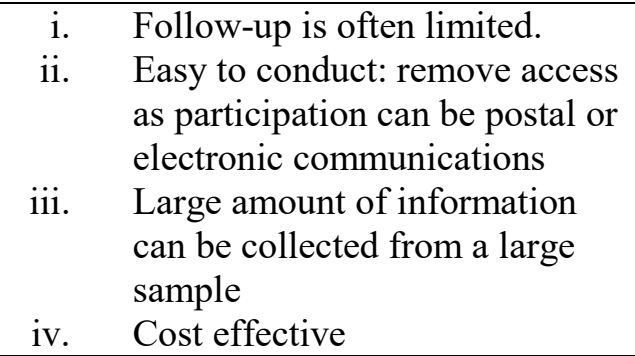 & $\begin{array}{l}\text { Group experts are selected. } \\
\text { Iteration process improves the } \\
\text { accuracy of results } \\
\text { Easy to conduct as participation can } \\
\text { be by postal or electronic } \\
\text { communication } \\
\text { cost effective }\end{array}$ & $\begin{aligned} \text { i. } & \text { Group experts are selected. } \\
\text { ii. } & \text { Response rate is not an issue } \\
\text { iii. } & \text { Follow-up is often limited } \\
\text { iv. } & \text { Rapid feedback and results } \\
\text { v. } & \text { Rich data and detailed information } \\
& \text { obtained. } \\
\text { vi. } & \text { It offers an opportunity to seek } \\
& \text { clarification }\end{aligned}$ \\
\hline Weaknesses & $\begin{aligned} \text { i. } & \text { Generally low response rate } \\
\text { ii. } & \text { Danger of recruiting non- } \\
& \text { capable respondents } \\
\text { iii. } & \text { Time-consuming process } \\
\text { iv. } & \text { Slow process to get the results }\end{aligned}$ & $\begin{array}{l}\text { Potential of low response rate } \\
\text { Follow-up is needed due to } \\
\text { iteration process. } \\
\text { Requires participant commitment } \\
\text { Can be time consuming if the } \\
\text { sample size is too large and the } \\
\text { questionnaire is lengthy. } \\
\text { Slow process from developing } \\
\text { questionnaires, collecting data and } \\
\text { obtaining consensus. }\end{array}$ & $\begin{aligned} \text { i. } & \text { Personnel needed, such as facilitators } \\
\text { ii. } & \text { and moderators. } \\
\text { iii. } & \text { Costly to conduct. } \\
\text { iv. } & \text { Face-to-face is required. } \\
\text { v. } & \text { Group pressure. } \\
\text { vi. } & \text { Communication problem and noise } \\
\text { vii. } & \text { Disagreements and irrelevant } \\
& \text { discussion may happen which distract } \\
& \text { from the main focus. } \\
\text { viii. } & \text { Difficult to conduct and manage if } \\
& \text { large number of participants } \\
\text { ix. } & \text { Lengthy analysis process. }\end{aligned}$ \\
\hline
\end{tabular}




\section{The Delphi approach as applied to the Malaysian refurbishment context}

The key stages in selecting suitable assessment themes and sub-themes applicable to the Malaysian context and subjecting them to the Delphi process are given in Figure 1.

Phase 1: Exploration

Themes identification

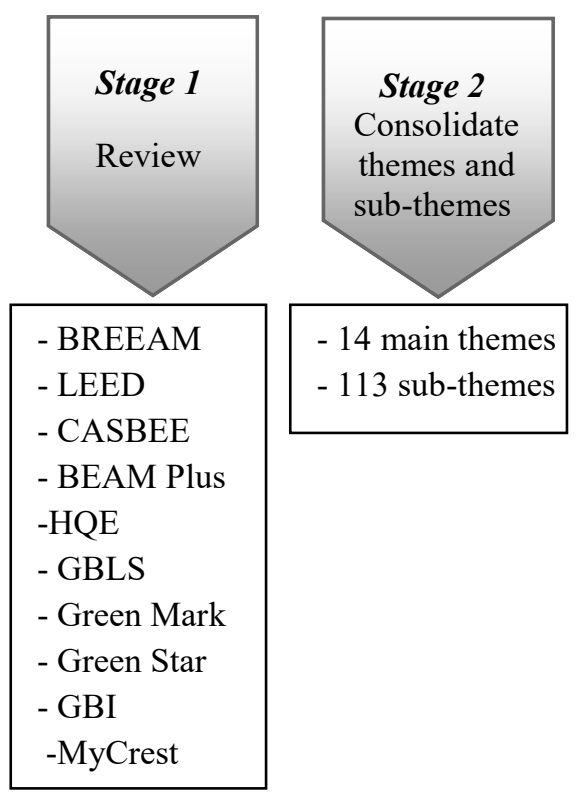

Phase 2: Delphi Process

Themes selection

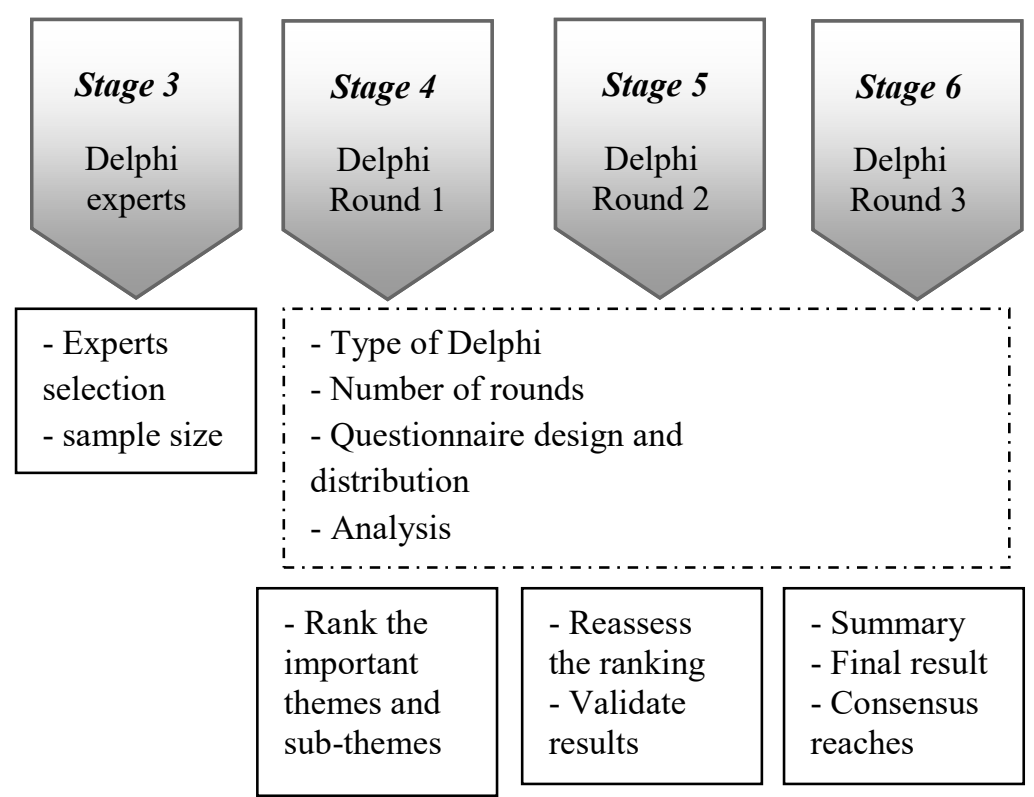

Figure 1: The development process for the assessment scheme

Phase 1 of the process started with the identification of themes. This is generally a review process, comparing several prominent assessment schemes for the purpose of identifying common assessment themes through the generation and consolidation of themes within existing assessment schemes [40]. Sustainable building practice and assessment vary by region, hence prominent international assessment tools could be adapted to the regional and local context by customizing the assessment criteria. Therefore, in stage 1, the outcome of the review was identification of 14 main assessment themes and 113 sub-themes. The main themes identified were management, sustainable site, transport, indoor environmental quality (IEQ), water, waste, material, energy, pollution, innovation, economic, social, culture and quality of services [25].

After identification of the themes, phase 2 of the Delphi process began with appointment of the Delphi experts. No specific optimum sample size for Delphi studies is advocated in the literature. Paliwoda [55] suggested that 10 to 18 members would be practical whereas Delbecq et al. [56] and 
Ziglio [57] stated that 10 to 15 subjects are sufficient. Ameyaw et al. [54] summarised that majority of the previous Delphi method in construction researches will employ a size between 8 to 20 and Hallowell and Gambatese [46] also suggested that a minimum of eight experts is required for conducting the Delphi process. The sample size should not be too small as it might not offer sufficient judgement regarding the target issue. In contrast, if too large a sample is used, there is potential for low response rates, and it is time consuming to obtain the consensus results [58]. Other studies who adopted Delphi approach with a small sample size include Chan et al. [52] who selected ten experts for providing opinions on the construction procurement selection and Kermanshachi et al. [59] invited ten experts to rank the project complexity indicators. Thus, a small number of experts is appropriate to use in Delphi approach. For the purposes of this Delphi study, a group of ten experts participated that comprising of four architects, three engineers, one project manager and two building surveyors.

Given that the primary consideration is not the number of Delphi experts $[45,60]$, and the results will not be generalizable [48], the main aim is to select experts with knowledge, experience and professional qualifications in the field and a deep understanding of the research problem [52,61]. The method focuses on eliciting the expert opinions on the specific issue [58]. The Delphi experts will have related backgrounds and experience of the research issue, be capable of contributing useful insights, and be willing to revise their previous judgements for the purpose of attaining consensus, and to commit time to several rounds of survey $[62,63]$. The selection of Delphi experts in this study was based on the possession of following capabilities: firstly, accreditation as a professional for the use of one or more sustainable assessment schemes; secondly, being an industry-based practitioner with experience of sustainability and green building; thirdly, possession of at least 10 years of experience and knowledge about the refurbishment of non-domestic buildings and finally, willingness to participate and commit time. The selection process will based on scoring system as illustrated in Table 3 . The scoring allocated on the level of experiences in three categories such as professional accreditation, industry involvement and level of knowledge. Scoring for more than six marks on all categories will be selected and contacted.

Table 3: Scoring system for Delphi experts' selection

\begin{tabular}{|c|c|c|c|c|}
\hline Years of experiences & $<5$ & $\geq 5$ & $\geq 10$ & $\geq 15$ \\
\hline Scores (marks) & 0 & 1 & 2 & 3 \\
\hline
\end{tabular}

Potential Delphi experts were contacted to explain the purpose of the study and the Delphi process. These individuals were contacted in order to obtain their consent to participate in the Delphi process. Loo [61] noted that it is crucial to fully inform identified experts on the commitment required 
as a result of participation. After that, a questionnaire and covering letter were distributed to the experts. The covering letter was important because the experts must be informed about the likely commitment needed to the Delphi process. Potentially several rounds would be required, and they had to ensure that completed questionnaires would have to be returned within a specified time so that the process could progress in a timely manner, thus avoiding cumulative delays to the completion of the Delphi process [61].

In the first round, the Delphi process usually begins with an open-ended questionnaire [58, 64]. However, this can be modified if desired to a structured questionnaire in round 1, provided that an extensive review of the literature has been carried out [58]. For the study described in this paper, the method was modified to a structured questionnaire, as an extensive literature review of well-known assessment schemes had been conducted. In the first-round questionnaire of the process, the experts were required to rank all the potential assessment themes and sub-themes obtained from the literature review stage. The rank order of each theme and sub-theme was thus produced to establish their preliminary priority in mean value as suggested by Ameyaw et al. [54]. The questionnaire also allowed the experts to add new themes and sub-themes that not on the original list. Ameyaw et al. [54] also found out that majority of the Delphi researches will adopt 5-point Likert scale to quantity the findings of Delphi experts. Thus, the 14 potential themes and 113 sub-themes identified were consolidated at the review stage and listed in questionnaire format with a 5-point Likert scale to rank themes from "not important" to "very important". Kendall's coefficient of concordance $(W)$ was adopted to find out the level of consensus among the Delphi experts. The $W$ value ranged from 0 (no agreement) to 1 (complete agreement) to indicates the degree of agreement between the Delphi experts on the mean of assessment themes and sub-themes.

Custer et al. [65] pointed out that three iterations of a survey are often sufficient to collect the data and to reach a consensus, and Day and Bobeva [66] observed that two to three rounds of iteration are common. Thangarathinam and Redman [64] stated that a minimum of two rounds are required, or three rounds if the first version is an open-ended questionnaire. They further explained that too many rounds would lead to fatigue and disengagement amongst the experts. Thus, in the present study three rounds of survey were conducted. Each round of the questionnaire was followed by an analytical stage to reflect the feedback of the experts. The questionnaire was sent by e-mail to all of the experts, and the data collected for these three rounds of survey were three months. The questionnaire in the second round allowed the Delphi experts to anonymously view the results from the first round, and to reassess their previous responses if necessary. This gave them an opportunity to refine, change and modify their thoughts after viewing the results. This step was critical to validate the results in order to achieve consensus. In the third round, the outcomes of the previous round were summarised and distributed for final judgement. The list of remaining themes and sub-themes and their final ratings reflected the overall results of the study. 
Next, expert interviews were conducted with another seven industry experts to verify the Delphi results. These experts were selected if they fulfilled the selection criteria such as they are accredited facilitators who have at least ten years of experience in the construction industry and refurbishment project. The potential experts were contacted to request for their permission to take part in the interview session. This process was conducted over a period of one month due to the availability of each expert. The interviews were conducted individually and the experts were asked a range of question related to the Delphi results. It enables a deeper interrogation and understanding of the results. Before the interview began, the researcher sought the consent from the experts to record the content of the interview. However, two of the experts refused and therefore the researcher recorded down the information by hand. The length of time for each interview varied one hour to one and half hours. Data obtained from the interviews were analysed by using manual content analysis. Interview results were then discussed and compared with the results from the Delphi surveys for the purpose of validation. The views and elaborations of the experts are discussed in Section 6.

\section{Results}

As previously stated, the objective of this study was to identify applicable assessment refurbishment themes and sub-themes for the Malaysian built environment. The importance of themes and sub-themes was determined by their mean scores. Sub-themes with a mean score less than 3 out of 5 were eliminated $[40,67]$ on the grounds that they were regarded as less important by the Delphi experts in comparison to other sub themes. Twelve assessment sub-themes were removed. These were site selection, contaminated land, electromagnetic pollution, biological contamination, de-odorising devices, grey water recycling, cooling tower water use, material ingredient, Nitrogen oxides (NOx) emissions, wind pollution, regional priority, and improved streetscapes. The results of the study are presented in sections 5.1 to 5.14. The Kendall's coefficient of concordance, $W$ value, was 0.769 , demonstrating a good level of agreement among the Delphi experts on the ranking of assessment themes and sub-themes. The interview results revealed that all of the experts agreed with the elimination of 12 assessment sub-themes from the review on the grounds that they were unrelated to refurbishment practice in the Malaysian context.

\subsection{Energy}

All the sub-themes of energy appeared to be regarded important, as shown in Figure 2. Energy performance of the heating, ventilation and air-conditioning (HVAC) system and building envelope 
ranked highly, in addition to energy-saving methods for optimum performance. Improved building energy efficiency was perceived as offering significant benefits by reducing the energy consumption of a building and a crucial element of undertaking refurbishment.

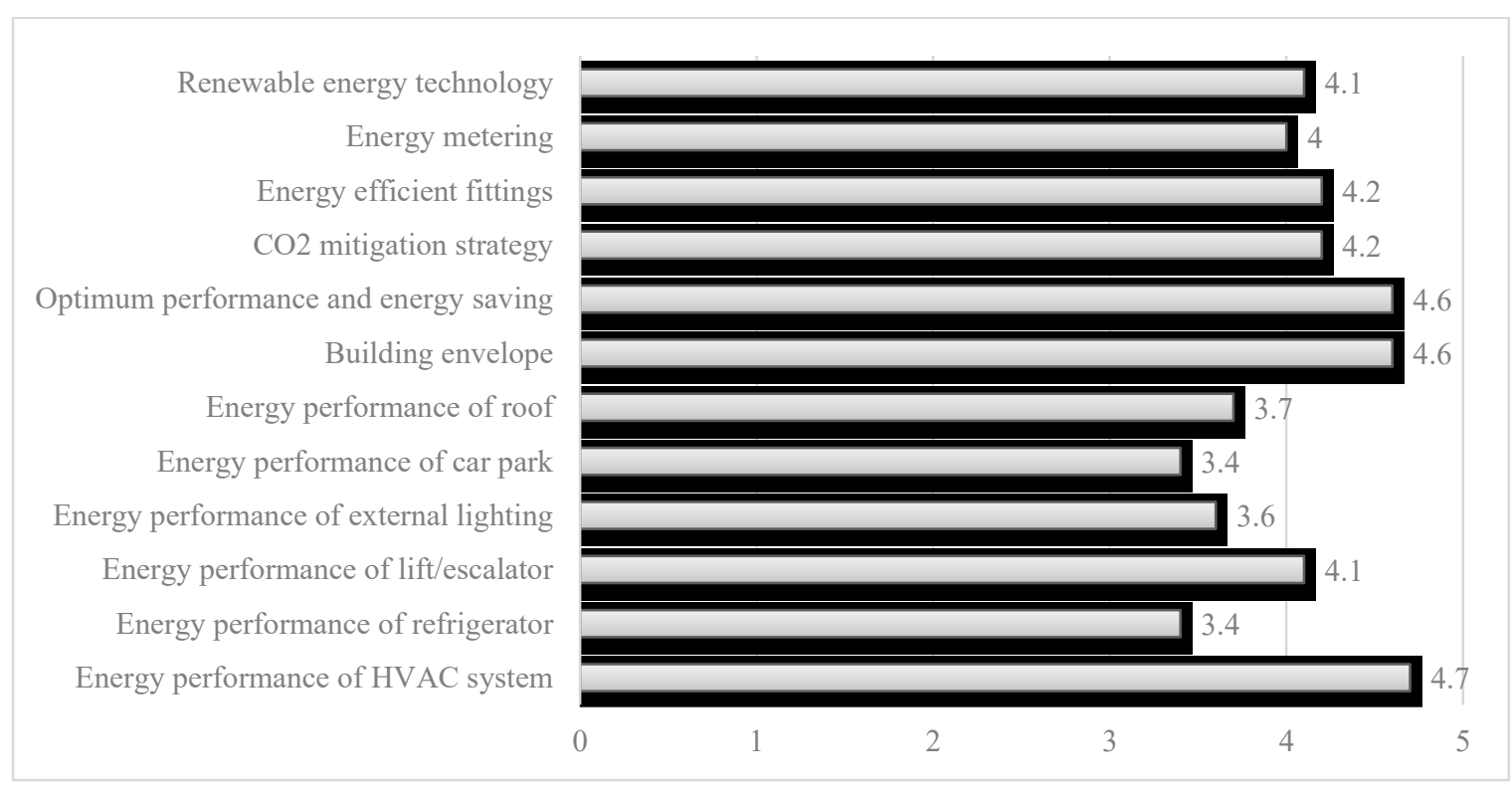

Figure 2: Mean score for energy theme

\subsection{Indoor environmental quality (IEQ)}

The assessment of IEQ comprised 26 sub-themes for ensuring the comfort and health and safety of occupants (Figure 3). 23 sub-themes achieved a mean score above 3.0, those falling below this mean score being electromagnetic pollution, biological contamination and de-odourising devices. It seems to be the case that electromagnetic pollution is not currently regarded as an issue in Malaysia. Daylight provision was ranked highest as adequate illumination by daylight will enhance the light environment for occupants to perform their daily tasks. 


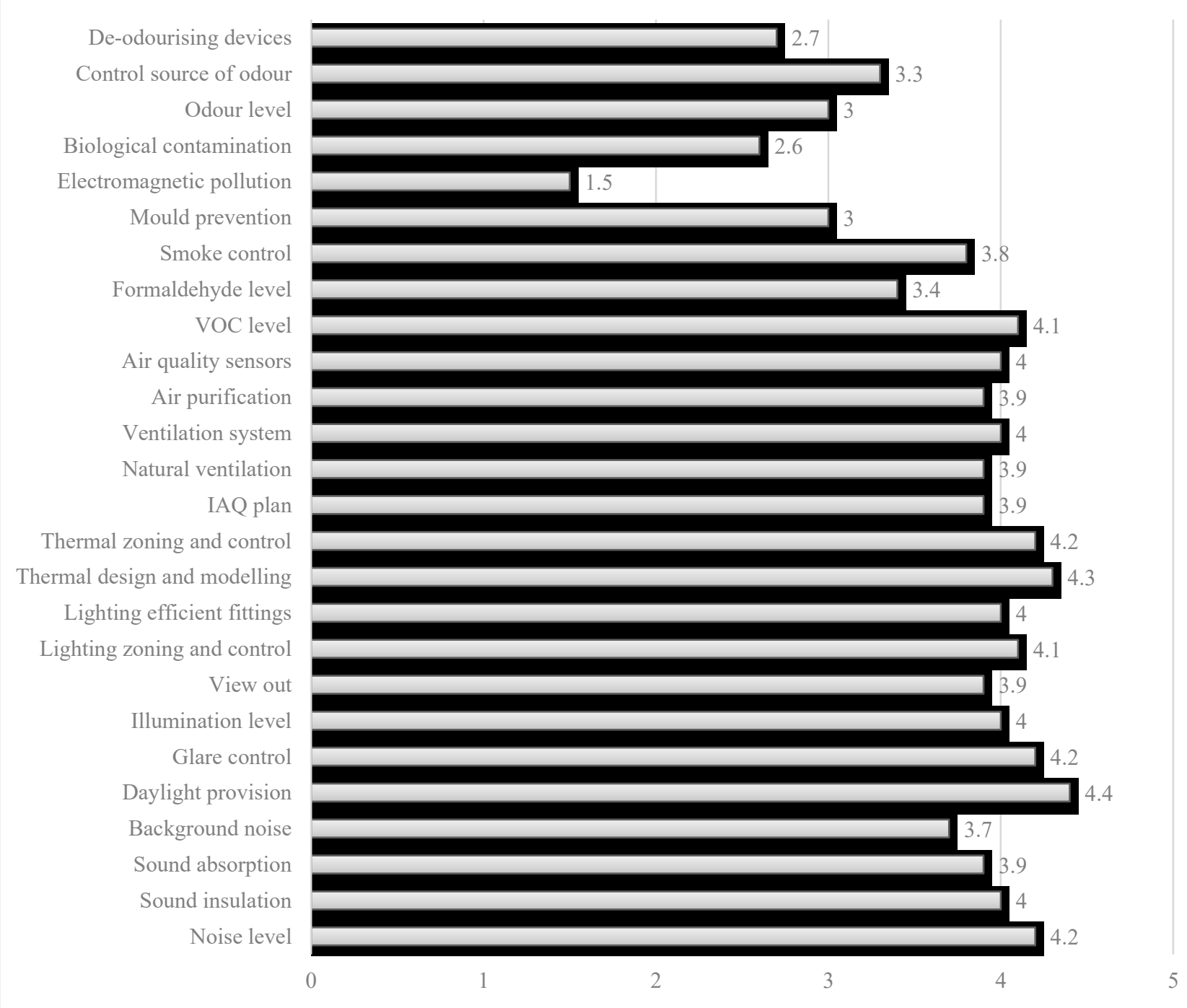

Figure 3: Mean score for indoor environmental quality theme

\subsection{Water}

The water assessment theme retained eight sub-themes after eliminating the sub-themes of cooling tower water use and grey water recycling (Figure 4). The purpose is to encourage sustainable water use through reducing consumption level and minimising water loss through leakage detection. Recycling, such as rainwater harvesting, is one of the viable strategies identified for reducing water consumption. 


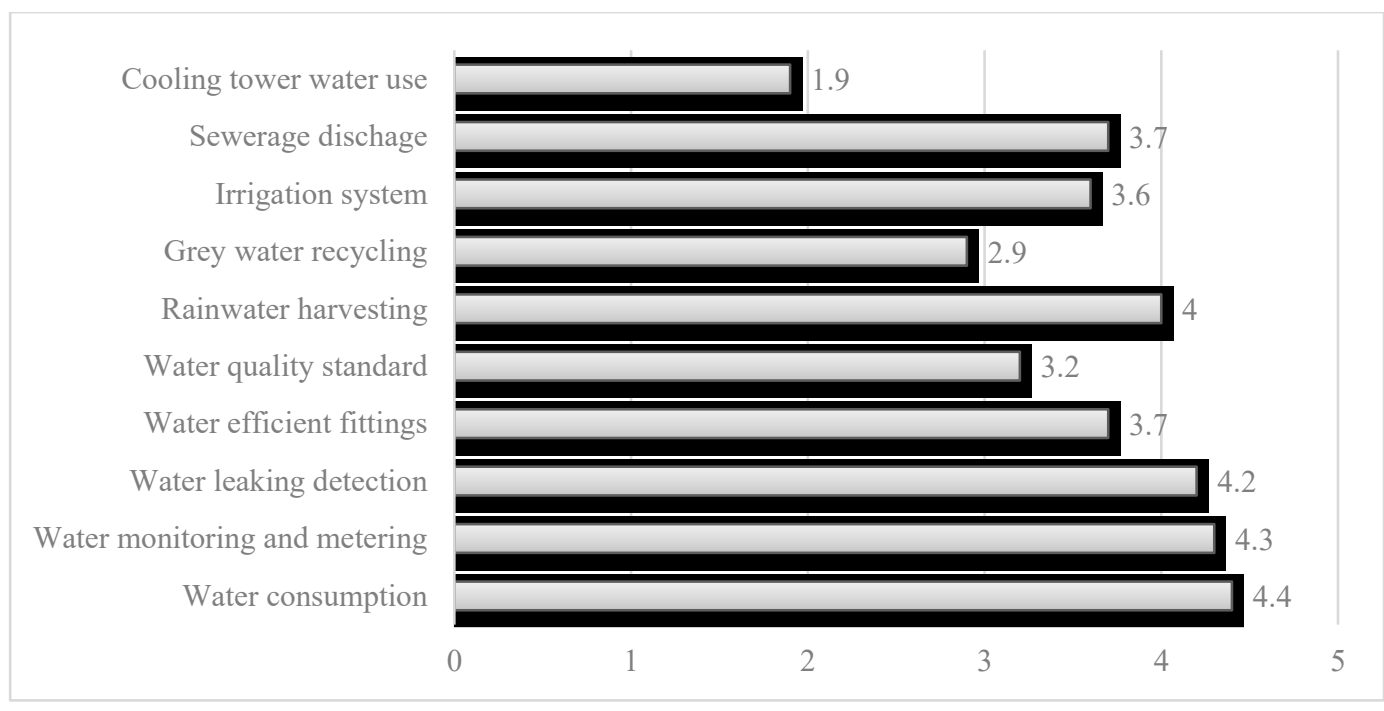

Figure 4: Mean score for water theme

\subsection{Waste}

The three waste sub-themes had equal levels of importance, as shown in Figure 5. Waste management is crucial as construction and building generate large amounts of waste during the refurbishment, operation and maintenance stages. Thus, improving waste management during construction and management of building is crucial during refurbishment by reducing waste generation and encouraging waste recycling and separation. The criteria should consider also how waste collection, storage sorting, recycling and disposal can be managed for the buildings after refurbishment. With adequate provisions for waste collection and sorting, the management of waste from buildings can be significantly improved.

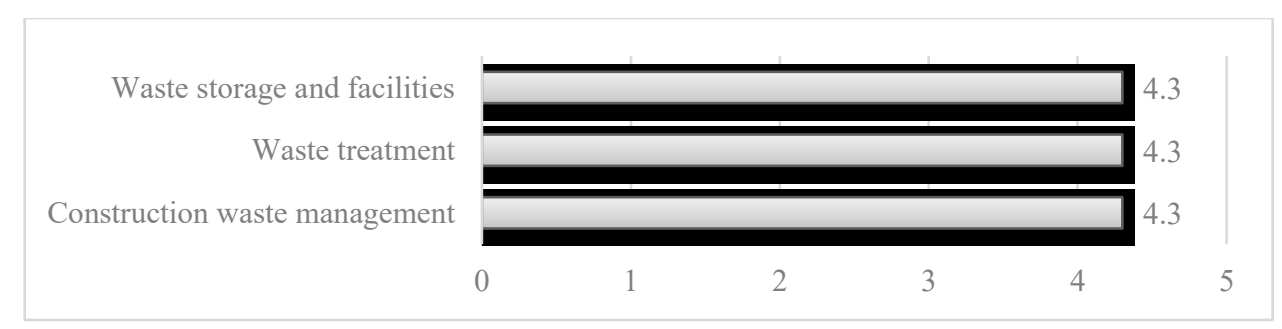

Figure 5: Mean score for waste theme

\subsection{Material}

The sub-theme of material composition was eliminated from material assessment theme (Figure 6). Building refurbishment generally emphasises the material selection. The use of low environmental 
impact material, recycled material, such as slag aggregate, and the reuse of existing structural frame material ranked high in assessment.

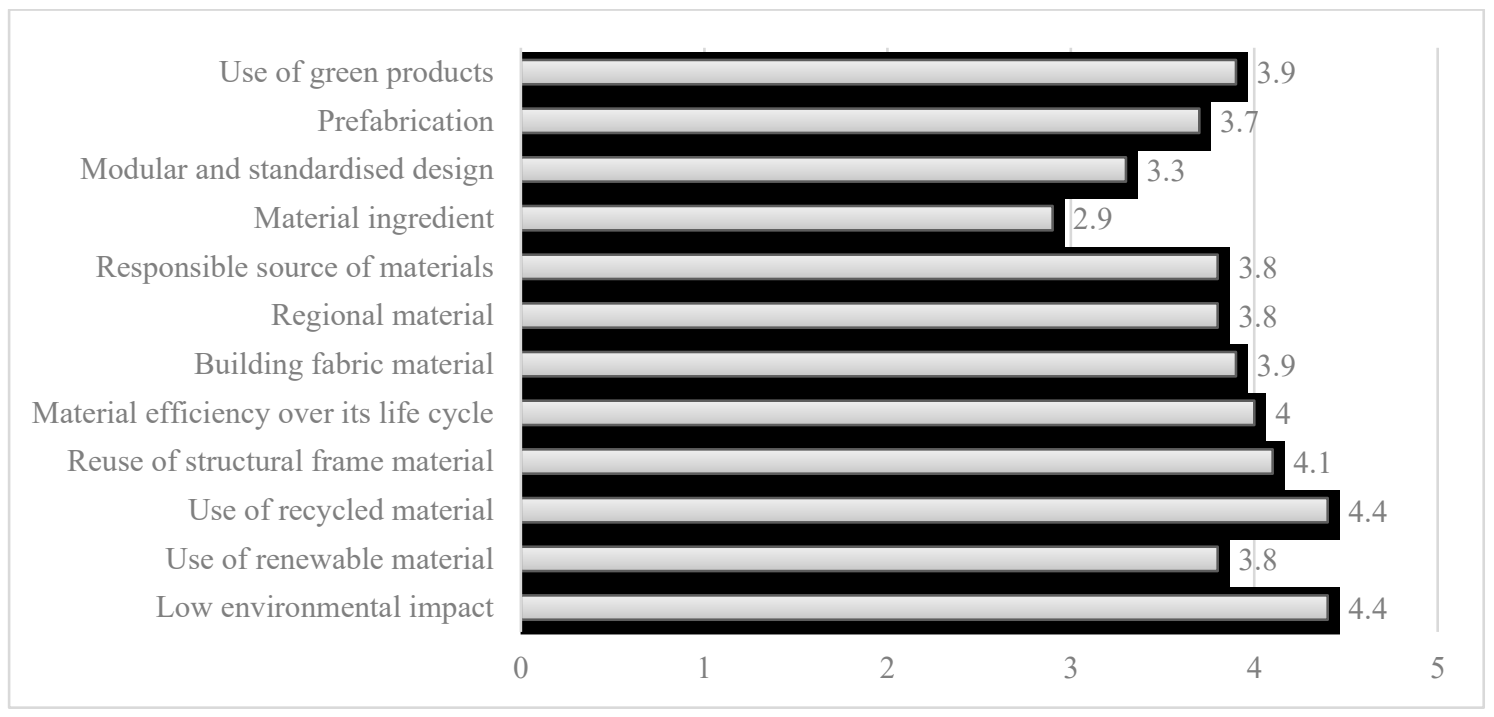

Figure 6: Mean score for material theme

\subsection{Transport}

This assessment theme encourages better access to transport for building users. Thus, it focuses on reviewing existing transport accessibility so that alternative ways can be implemented during refurbishment to reduce car journeys which in turn could reduce congestion, pollution and $\mathrm{CO}_{2}$ emission. Refurbishment often an opportunity to enhance the accessibility by providing alternative travel route to encourage walking, cycling and use of public transport. Based on the result as shown in Figure 7, the sub-themes of public transport accessibility and the associated car parking capacity were ranked highest. Proximity to a public transport network would encourage the building's users to use public transport to work, making it possible to limit the provided car parking capacity to reduce car usage and transport emissions.

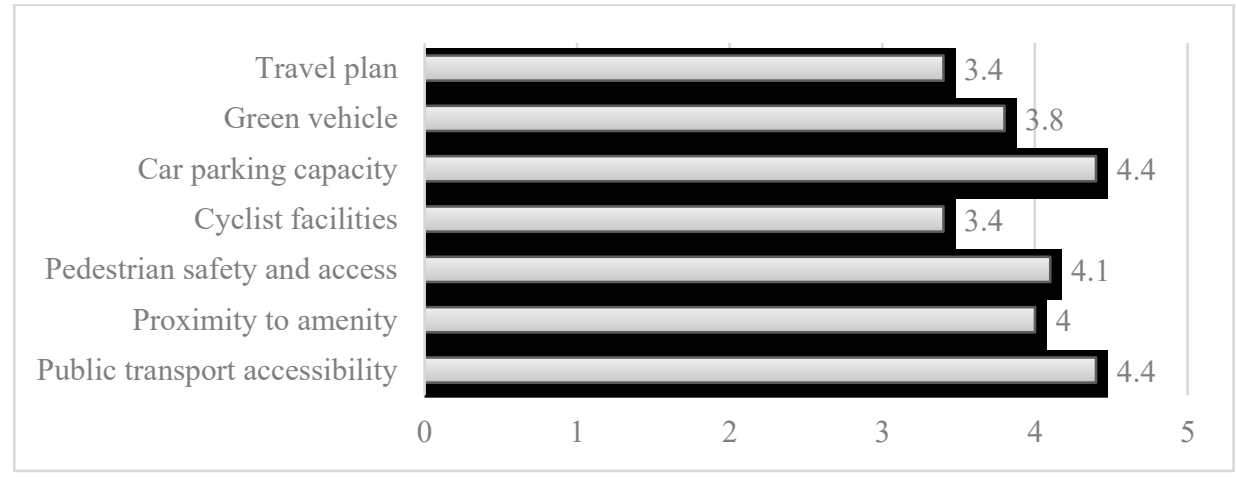


Figure 7: Mean score for transport theme

\subsection{Management}

The management assessment theme was to encourage the project team to adopt sustainable and good practices throughout the project life cycle. All four sub-themes scored above 4.0 and were retained (Figure 8). Project brief and design was deemed to be the most important, indicating the importance of assessing the feasibility of the refurbishment project at an early stage, for proposing suitable refurbishment options that suit the client's budget and goal.

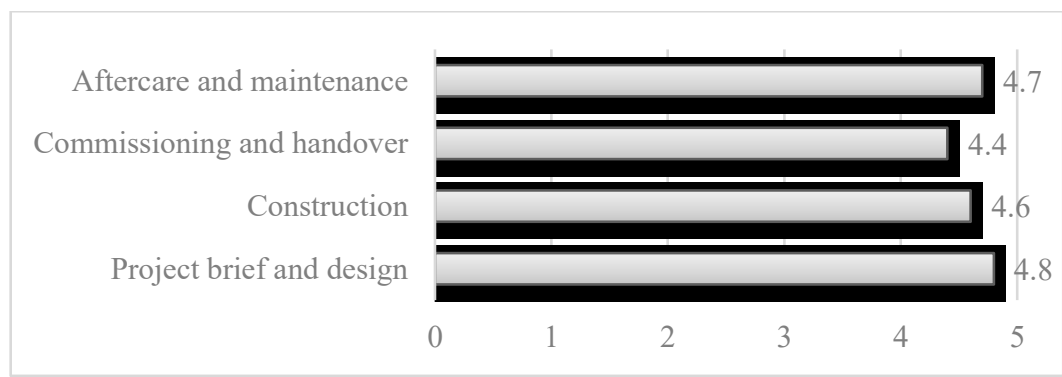

Figure 8: Mean score for management theme

\subsection{Quality of Services}

All five of the quality of service sub-themes scored over 4.0 (Figure 9). The assessment of service functions is to keep the building in good condition in the long term. The most important sub-theme was safety and security, followed by maintenance.

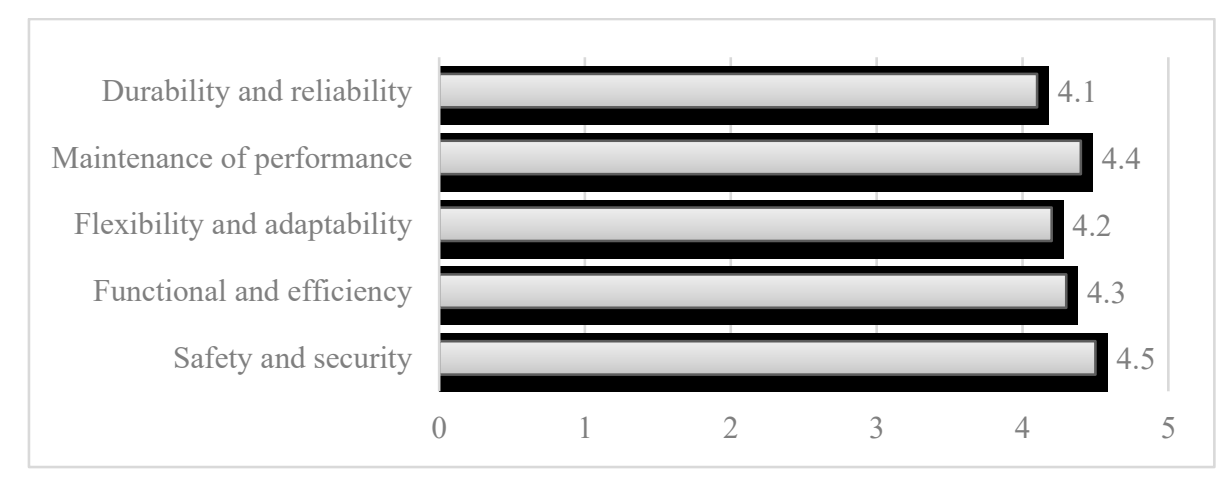


Figure 9: Mean score for quality of service theme

\subsection{Site Sustainability}

The site sustainability assessment theme (Figure 10) evaluated the site on which the building is built, the land used and its ecological value. The sub-themes of site selection and land contamination scored less than 3.0 and were eliminated from the assessment; both are applicable to new building and are rarely relevant to refurbished buildings. Whereas, the protection of ecological value and mitigation of ecological impact scored highest. Thus, existing positive ecological features (if any) within the building and site have to be protected prior to and during refurbishment to avoid damaging site ecology. There is a potential for a site to increase its ecological and biodiversity value through appropriate planning during refurbishment. By incorporating this process into the assessment scheme, it provides the opportunity to reward the project team that contribute to enhancing biodiversity and improving living environment during refurbishment.

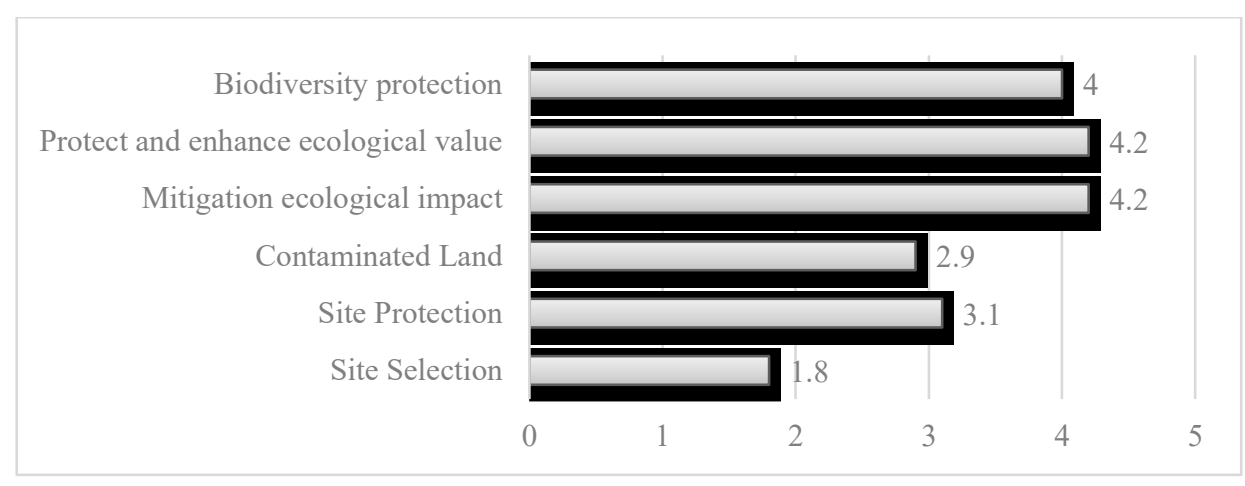

Figure 10: Mean score for sustainable site theme

5.10 Pollution

Two of the nine sub-themes were ranked below 3.0: wind pollution and NOx emissions (Figure 11). Wind pollution is not applicable in the Malaysian context. The heat island effect ranked highest, because of Malaysia's hot humid temperature with bright clear skies throughout the year; reducing the heat island by planting and landscaping is crucial to avoid overheating and rising temperatures. 


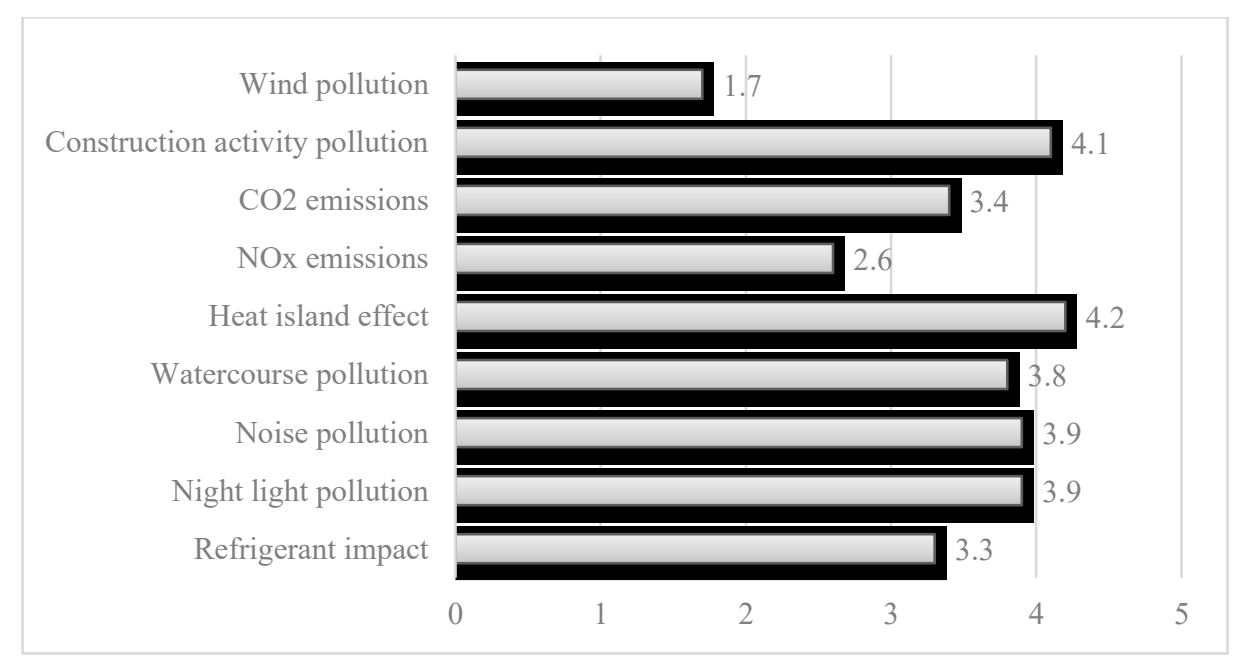

Figure 11: Mean score for pollution theme

\subsection{Innovation}

All three sub-themes to support innovation in the construction industry were remained. Any improvement that are able to support good performance and environmental benefits are encouraged (Figure 12).

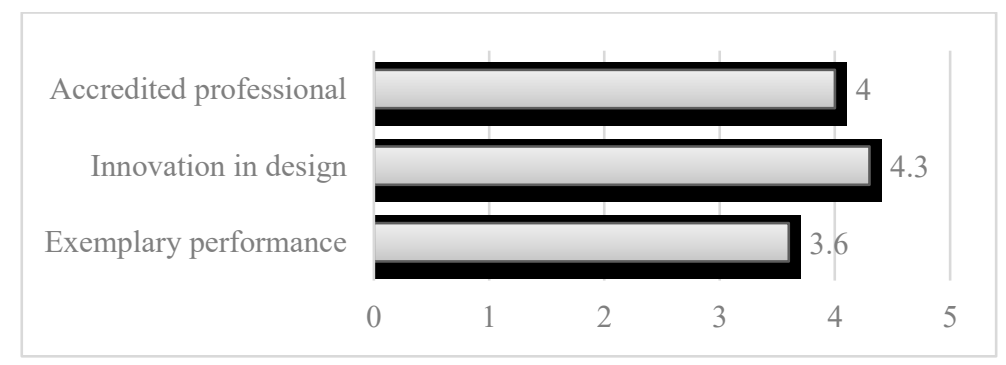

Figure 12: Mean score for innovation theme

\subsection{Economic}

The economic theme's eight sub-themes for assessment (Figure 13) are often overlooked in building assessment schemes. However, this theme is a fundamental aspect of sustainable development and evaluation of the feasibility of a refurbishment project. 


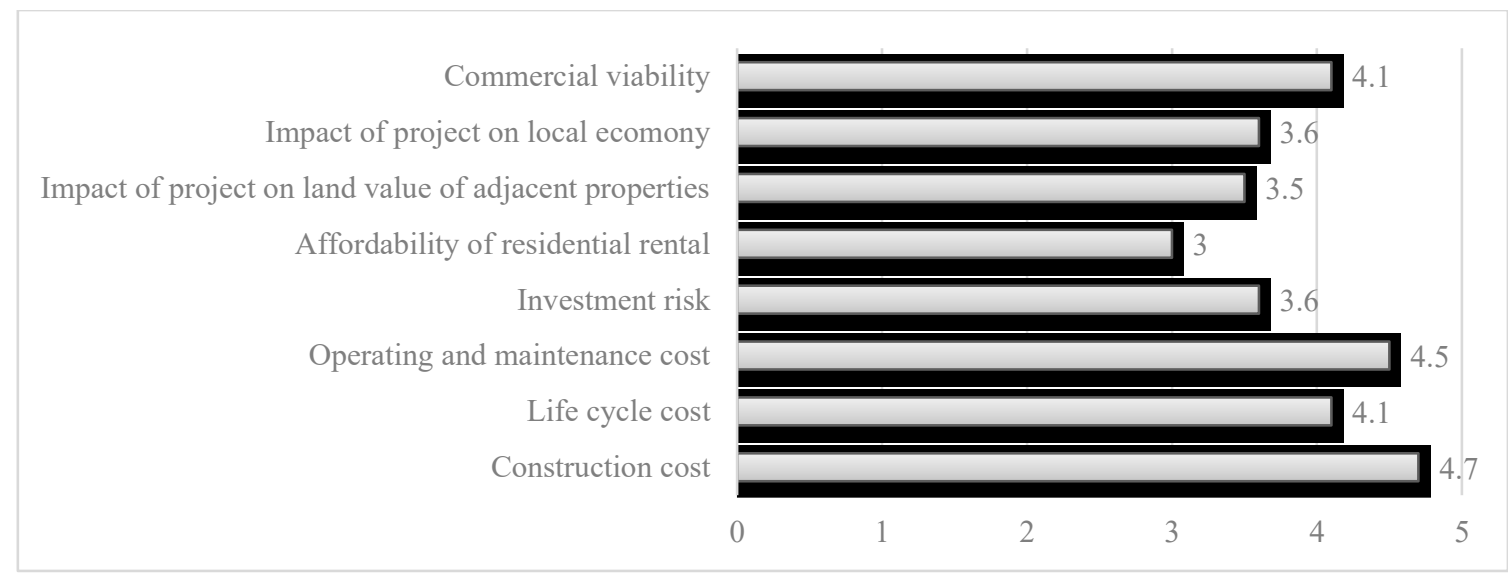

Figure 13: Mean score for economic theme

\subsection{Social}

In Figure 14, regional priority scored less than 3.0 and was eliminated; the other three sub-themes remained. The social aspect is one of the fundamental features of sustainable development, catering for the well-being of the occupants. It can be achieved by providing building amenities, public open space and enhancing the social welfare of disabled persons.

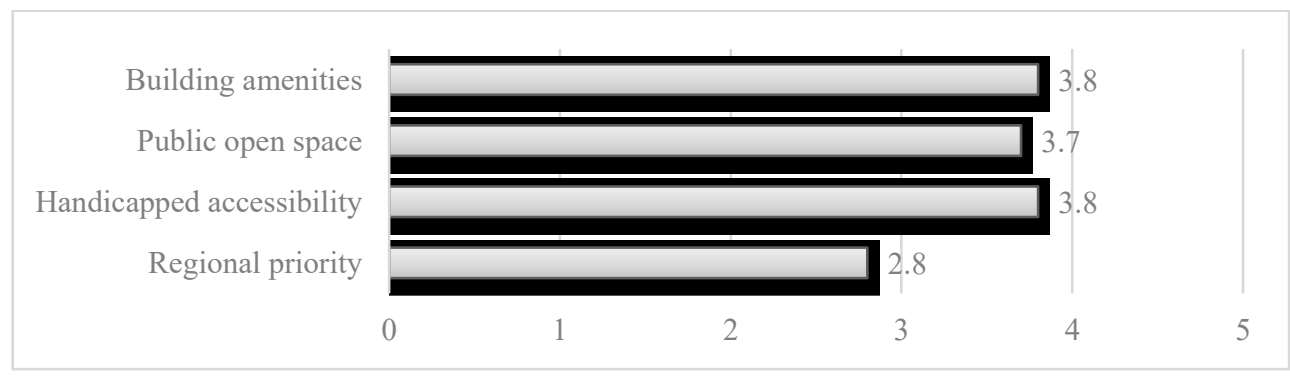

Figure 14: Mean score for social theme

\subsection{Culture}

Figure 15 showed that improving streetscapes scored less than 3.0, leaving three sub-themes. Local culture built up over the long course of history was an important asset that should be preserved. If the existing buildings contain historic interior and exterior spaces, they should be restored to enhance the local culture. 


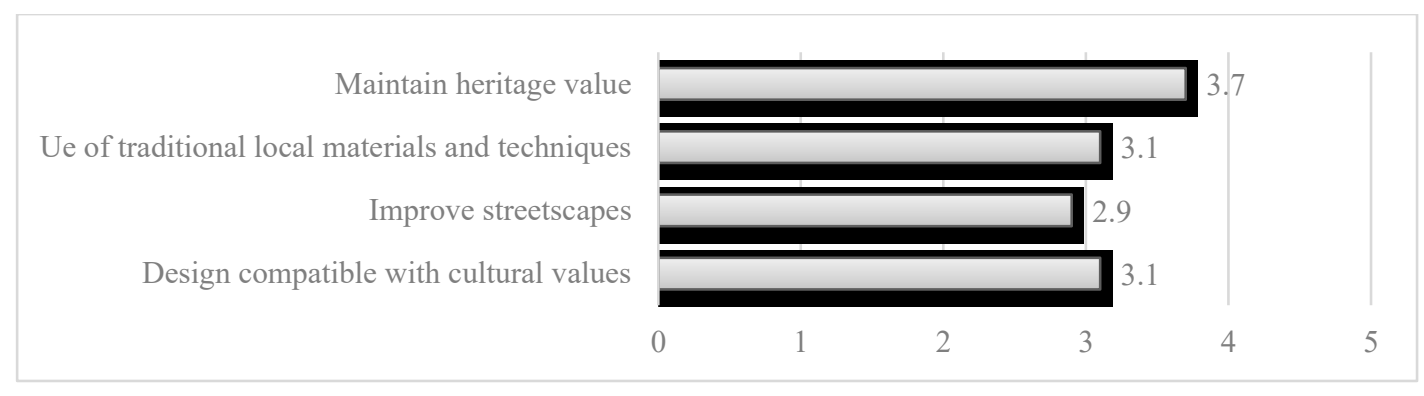

Figure 15: Mean score for culture theme

\section{Discussion}

This study revealed that energy and IEQ were ranked as the top priorities for building refurbishment (Figure 16) as supported by Li et al. [22]. Non-domestic buildings especially office buildings tend to have higher energy and comfort demands [68]. The energy performance of HVAC, lifts and lighting were ranked high. Saidur [6] in his study of identifying major types of energy consumption in Malaysian office buildings found that on average air-conditioning equipment consumed $57 \%$ of the energy, followed by $19 \%$ for lighting, $18 \%$ for lifts and $6 \%$ for general office equipment. The Delphi results were aligned with these findings as air conditioning, lifts and lighting are major energy consumers in non-domestic buildings, and their energy performance should be assessed to determine how much improvement and saving could be achieved through refurbishment. Most old buildings are equipped with obsolescent equipment and fittings, and it is essential to replace this with energy efficient equipment and appliances to reduce energy consumption. Hence, the subthemes optimum performance and energy saving were highly ranked. 


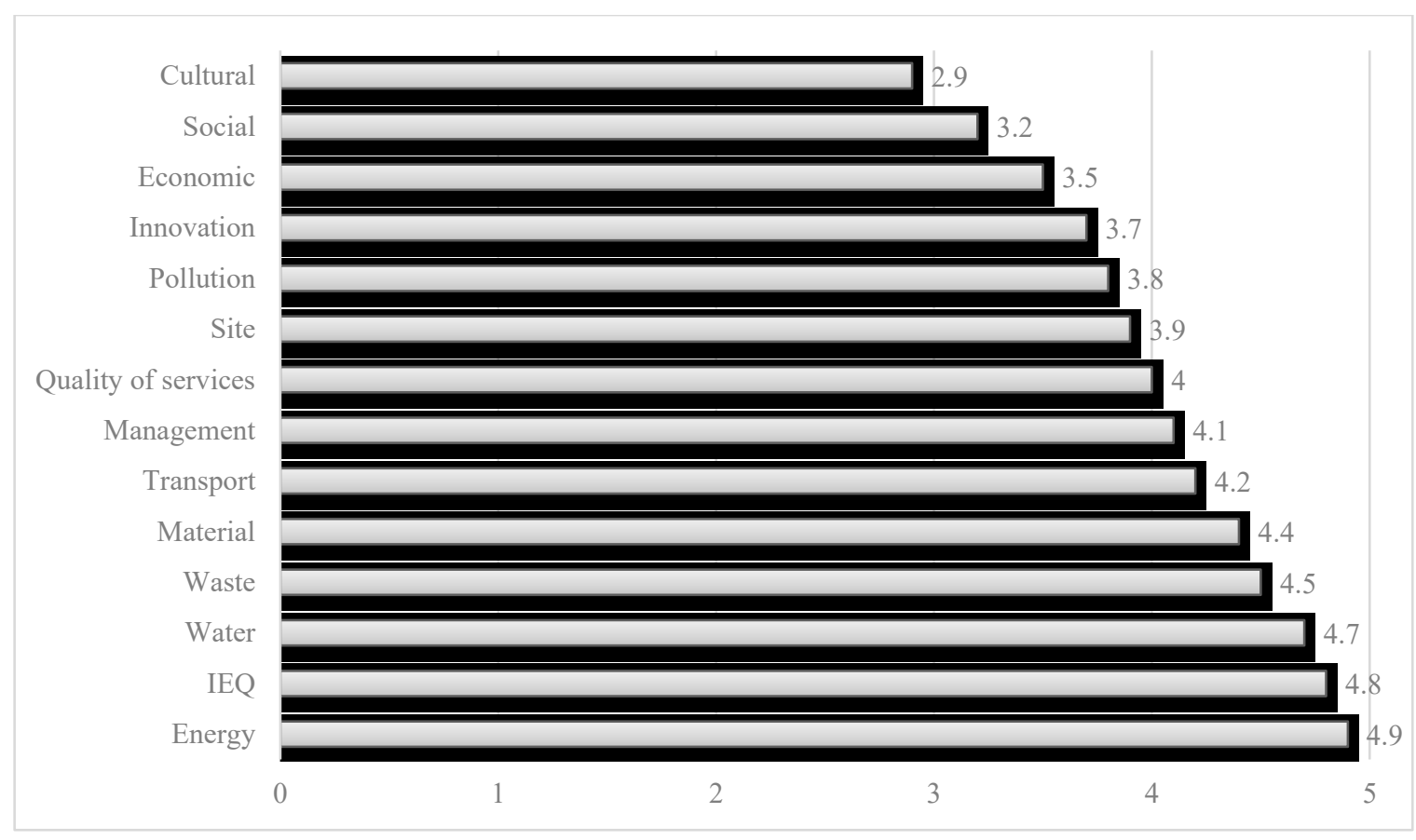

Figure 16 Mean scores of assessment themes

IEQ ranked second highest, and it was noted that Malaysia suffered from a severe pollution induced haze in 2015 [69], which also affected the country's air quality and people's health. Thus, it is essential to enhance the indoor air quality of a building for the beneficial of building occupants. IEQ must be maintained or improved during refurbishment, especially as existing old buildings contain old ventilation systems, and occupants spend most of their time inside the building. A clean indoor environment and the achievement of thermal comfort can enhance the productivity of workers in the building. Most of the interviewees supported that energy and IEQ are the top priority in Malaysian assessment scheme.

Water consumption assessment was also ranked as being of high importance. In Malaysia, water shortages are an ongoing crisis [70], and urgent action must be taken by responsible parties to mitigate this crisis. Malaysia has the highest rate of water consumption rate per head in Southeast Asia [71]. In order to avert crisis in the future, it is vitally important to measure and control water consumption within buildings, especially water-consuming components such as water closets and urinals. Water-efficient fittings and appliances should replace old fittings in existing buildings to reduce consumption. In some cases, water free appliances might be appropriate.

Although Malaysia is relatively free from major natural disasters (typhoons, earthquakes and volcanic eruptions), the country regularly faces the risk of flooding and associated loss of life and property damage, especially during the annual monsoon period between October and March. Both natural and manmade factors contribute to the risk of flooding. Manmade factors include poor drainage 
design and land pressure, and natural factors include heavy monsoon rainfall and rainstorms. Kong et al. [72] identified inadequate drainage systems as a major factor in the occurrence of flooding. The risk of watercourse pollution is an essential consideration. For instance, site discharges should be managed with appropriate drainage design. Uncontrolled run-off can cause flooding on site. Buildings situated in floor-risk zones should adopt floor resistance strategies or else reduce impervious areas by using permeable hard standing material. This is especially applicable to Kuala Lumpur and Selangor, as many old buildings in these areas are situated in flood zones and suffer during heavy rain. Flash flood inundation of car parking has caused hundreds of cars to be submerged and damaged in recent years [73]. Consideration of the use of rainwater harvesting is essential, where the National Hydraulic Research Institute has proposed it as one of the strategies to mitigate the problem flooding [74]. The water stored can be used for landscape irrigation and sanitary flushing and is an essential issue to consider during the refurbishment of existing buildings, as encouraged by Shaaban [74]. One of the expert during the interview supported that the refurbishment could be a viable solution to solve the issue of flooding.

It is important to note that the assessment of quality of service is not covered in all existing assessment schemes although it is important for refurbishment practice. Most refurbishment projects are carried out in limited space, which increases the difficulty of access and results in uncertainty and risk to the occupants of nearby buildings and to the surrounding environment. Evaluation of safety and security is essential to provide sufficient and appropriate protection to the neighbouring occupants as confirmed by most of the expert interviewees. The assessment of flexibility and adaptability is also necessary in order to cater for future building expansion and change. Design proposals that allow for flexibility in the layout of buildings are to be encouraged during refurbishment, allowing building layouts to be changed or removed without affecting the entire structure of the building. As the number of buildings may grow rapidly and the usage of premises may change, measures to accommodate future changes or renovation should be implemented to reduce further waste during renovation.

In terms of economic themes, financial considerations are essential in refurbishment practices. However, it is not covered in most of the existing schemes [25, 68]. The feasibility of the refurbishment project should be assessed at the initial stage in order for the project consultants to propose suitable refurbishment options that meet the client's budget and expectations. As stated by Ding [9], green buildings are potentially very costly to construct, hence, an acceptable financial return is essential. This is applicable to refurbishment projects, especially non-domestic buildings such as offices. Payback period and other measures of commercial viability should be taken into account as this leads to decisions about the affordability of residential rental. Majority of the interviewees mentioned that most of the assessment themes do not measured economics aspect comprehensively as they are emphasising in improving environmental aspect of a building. 
All these identified critical assessment themes need to be considered in any Malaysian environmental assessment scheme for the refurbishment of non-domestic buildings. A refurbishment scheme for Malaysia that suits the local context, setting a benchmark for refurbishment practice against which to establish minimum performances standards is essential. The identification indicators are crucial for the development building assessment schemes [43]. The findings of the list of assessment themes and sub-themes could be applied by other countries without individual refurbishment schemes in order to develop a localized refurbishment assessment scheme. For countries with existing refurbishment schemes, assessment themes and sub-themes for quality of services and economics could be added to complement existing assessment themes. It is noted that the existing prominent assessment schemes such as BREEAM and LEED do not include assessment of quality of services and economics. It is suggested that refurbishment schemes should assess buildings not merely by focusing on the conventional approach of limiting environmental impact and creating healthier buildings, but also by considering the quality of services and economic aspects. This failure to target social and economic considerations is the most serious deficiency in existing refurbishment assessment schemes in most countries. As suggested by Kang et al. [75], a sustainable building assessment scheme should comprise of environmental, economic and social.

\section{Conclusion}

The experts involved in the Delphi study reached a consensus on applicable assessment themes and sub-themes for refurbishment assessment in Malaysia after three rounds of survey. The results of the Delphi study identified 14 themes and 113 sub-themes that are important in assessing Malaysian refurbishment projects. The results were validated through expert interviews. Energy, IEQ and water were ranked highest by the experts. These are relevant to existing old buildings in Malaysia that are not sustainable, built with poor ventilation provision and high energy consumption. The water assessment theme is related to Malaysia's flooding scenario, which requires immediate mitigating action, by rainwater harvesting and proper drainage systems. Other essential themes for assessing refurbishment include financial considerations and quality of services. Due to the nature of refurbishment, it is necessary to evaluate the viability of projects and also assess the safety and security of the building, as refurbishment involves a high level of uncertainty, such as difficult assess to the site. After successfully using the Delphi approach to determine a schedule of applicable assessment themes, the next phase of this research will be developing a weighting system by allocating scores to each the applicable assessment theme by using analytic hierarchy process (AHP) and designing a classification system for building rating. 
Although the study has achieved the aim stated in the introduction, the study has several limitations. The sample size chosen was considered relatively small. Thus, this study is considered exploratory as the Delphi experts chosen are from various background so that various perspectives could be taken into consideration. The relevant assessment themes and sub-themes identified in this study will improve the understandings of practitioners such as green building assessors and policy makers in assessing refurbishment. It in turns could allow for further comparisons and discussion to improve or refine the existing sustainable assessment frameworks or contribute to building assessment regulations. It is essential to formulate a tool for evaluating and assessing the impacts, performance and improvement potentials of refurbished existing buildings, not only on environmental aspects, but also economics and social aspects.

\section{Acknowledgements}

This research is supported by British Council Newton-Ungku Omar Institutional Links Fund (172726659) through University of Malaya Institute of Research Management \& Monitoring (IPPP) (IF009-2015 \& RK005-2015).

\section{References}

[1] Xing, Y., Hewitt, N., Griffiths, P., 2011. Zero carbon buildings refurbishment - A Hierarchical pathway. Renewable and sustainable energy reviews. 15(6), 3229-36.

[2] Pombo, O., Rivela, B., Neila, J., 2015. The challenge of sustainable building renovation: assessment of current themes and future outlook. Journal of Cleaner Production. 123, 1-13.

[3] Asia Business Council ( $A B C)$, 2007. Building energy efficiency: why green buildings are key to Asia's future, Asia Business Council Publication, Hong Kong.

[4] United Nations Environment Programme (UNEP), 2009. Buildings and Climate Change. Retrieved from unep.org sbei/pdfs/SBCI BCCSummary.pdf (acessed 24.08.15).

[5] World Business Council for Sustainable Development (WBCSD), 2009. Energy efficiency in

buildings: business realities and opportmities. Retrieved from

http://www.wbesd.org/web/eeb/Energyefficiencyinbuilding.pdf (accessed 24.08.15).

[6] Saidur, R., 2009. Energy consumption, energy savings, and emission analysis in Malaysian office buildings. Energy Policy. 37 (10), 4104-13.

[7] Shika, S. A., Sapri, M., Abdullah, S., Jibril, D., Shahril, A. R., 2012. Towards an integrative sustainability concept for retrofitting commercial office buildings in Malaysia. Retrieved from http://s3.amazonaws.com/academia.edu.documents/31059489/CRES INTEREC_PAPER.pdf?A WSAccessKeyId $=$ AKIAJ56TQJRTWSMTNPEA $\&$ Expires $=1443633496 \&$ Signature $=\mathrm{k} 5 \mathrm{aCN} 2 \mathrm{D}$ TW6JnmhxTCqfHyD8Qbwc\%3D\&response-content-disposition=inline (accessed 01.03.16).

[8] Crawley, D., Aho, I., 1999. Building environmental assessment methods: applications and development trends. Building Research \& Information. 27 (4-5), 300-308.

[9] Ding, G. K. C., 2008. Sustainable construction - The role of environmental assessment tools. Journal of environmental management. 86 (3), 451-464.

[10] Cole, R. J., 1999. Building environmental assessment methods: clarifying intentions. Building Research \& Information. 27 (4-5), 230-246. 
[11] BREEAM, 2015. BREEAM International Refurbishment and Fit-out. Retrieved from: http://www.breeam.com/refurbishment-and-fit-out (accessed 24.08.15).

[12] CASBEE, 2015. CASBEE homepage. Retrieved from http://www.ibec.or.jp/CASBEE/english index.htm (accessed 24.08.15).

[13] Chang, C. Y., Lin, H. T., Ho, M. C., 2012. Sustainability assessment tool of green building renovation in Taiwan: an introduction to EEWH-RN. International Journal of Sustainable Construction. 1 (1), 25-31.

[14] GBL, 2013. Green Building Label System. Retrieved from http://green.abri.gov.tw/arten.php?no=61\&SubJt=Green+Building+Label (accessed 24.8.15).

[15] USGBC, 2011. USGBC homepage. Retrieved from http://www.usgbc.org/ (accessed 24.08.15).

[16] HKGBC (Hong Kong Green Building Council), 2012. BEAM Plus V1.2 for New Buildings. Retrieved from https://www.hkgbc.org.hk/upload/beamdocuments/BEAM-Plus-NB-1-2Manual.pdf (accessed 24.08.15).

[17] GBCA (Green Building Council Australia), 2014. Green Star - Design \& As Built. Retrieved from https://www.gbca.org.au/green-star/green-star-design-as-built/ (accessed 24.08.15).

[18] HQE (Haute Qualité Environnementale), 2013. HQE homepage. Retrieved from http://www.behqe.com/cerway/essentials (accessed 24.08.15).

[19] BCA (Building and Construction Authority), 2012. Green Mark homepage. Retrieved from http://www.bca.gov.sg/GreenMark/green_mark themes.html (accessed 24.08.15).

[20] GBI, 2011. Green Building Index Assessment Themes for Non-residential Existing Building. Retrieved from http://new.greenbuildingindex.org/Files/Resources/GBI\%20Tools/GBI\%20 NREB\%20Non-Residential\%20Existing\%20Building\%20Tool\%20V1.1\%20Final.pdf (accessed 24.08.15).

[21] CIDB (Construction Industry Development Board), 2013.Malaysian Carbon Reduction \& Environmental Sustainability Tool - MyCREST. Retrieved from https://www.cidb.gov.my/cidbv4/index.php?option=com content\&view=article\&id=1110:malays ian-carbon-reduction-environmental-sustainability-tool-mycrest\&catid=37\&Itemid=275\&lang $=$ en (accessed 24.08.15).

[22] Li, Y., Chen, X., Wang, X., Xu, Y. and Chen, P.H., 2017. A review of studies on green building assessment methods by comparative analysis. Energy and Buildings, 146, 152-159.

[23] Radhi, H., 2009. Can envelope codes reduce electricity and CO2 emissions in different types of buildings in the hot climate of Bahrain? Energy. 34 (2), 205-215.

[24] Begum, R. A., Pereira, J. J., 2010. GHG emissions and energy efficiency potential in the building sector of Malaysia. Australian Journal of Basic and Applied Sciences. 4 (10), 5012-5017.

[25] Kamaruzzaman, S. N., Lou, E. C. W., Zainon, N., Mohamed-Zaid, N. S., Wong, P. F., 2016. Environmental Assessment Schemes for Non-Domestic Building Refurbishment. Ecological Indicators. 69, 548-558.

[26] Ng, S. T., Gong, W., Loveday, D. L., 2014. Sustainable Refurbishment Methods for Uplifting the Energy Performance of High-rise Residential Buildings in Hong Kong. Procedia Engineering. 85, 385-392.

[27] Nik, V. M., Mata, E., Kalagasidis, A. S., 2015. A statistical method for assessing retrofitting measures of buildings and ranking their robustness against climate change. Energy and Buildings. $88,262-275$.

[28] Ali, A. S., Kamaruzzaman, S. N., Salleh, H., 2009. The characteristics of refurbishment projects in Malaysia. Facilities. 27 (1/2), 56-65.

[29] The Chartered Institute of Building (CIOB), 2011. Buildings under refurbishment and retrofit. Retrieved from http://www.carbonaction2050.com/sites/carbonaction2050.com/files/documentattachment/Buildings\%20under\%20Refurb\%20and\%20Retrofit.pdf (accessed 14.03.16).

[30] DOE, 2010. Buildings Energy Data Book, Office of Energy Efficiency and Renewable Energy. Washington, DC, USA: U.S. Department of Energy.

[31] Economic Planning Unit (EPU), 2015. Eleventh Malaysia Plan 2016-2020. Retrieved from http://rmk11.epu.gov.my/index.php/en/ (accessed 17.09.15).

[32] Quah, L. K., 1988. An evaluation of the risks in estimating and tendering for refurbishment work. Heriot-Watt University. 
[33] Rahmat, I., Torrance, V. B., Ezanee, A. H., 2003. Refurbishment cycles and the management of refurbishment project, UiTM Research Centre, Shah Alam, Selangor, Malaysia.

[34] Mansfield, J., 2009. Sustainable refurbishment: policy direction and support in the UK. Structural Survey. 27 (2), 148-161.

[35] Ma, Z., Cooper, P., Daly, D., Ledo, L., 2012. Existing building retrofits: Methodology and stateof-the-art. Energy and buildings. 55, 889-902.

[36] Ahmed, A. Z., Nayar, C. V., 2008. Integrating sustainable energy in buildings: a case study in Malaysia. Paper presented at the FAU Conference, Copenhagen, Denmark.

[37] INDC, 2015. Intended Nationally Determined Contribution (INDC) of the Government of Malaysia. Submitted to the United Nations Framework Convention on Climate Change in 2015. Retrieved from https://goo.gl/Vh0caO (Accessed 24 September 2017).

[38] Mickaityte, A., Zavadskas, E. K., Kaklauskas, A., Tupenaite, L., 2008. The concept model of sustainable buildings refurbishment. International Journal of Strategic Property Management. 2 (1), 53-68.

[39] Cole, R. J., 2005. Building environmental assessment methods: redefining intentions and roles. Building Research and Information. 33 (5), 455-467.

[40] Alyami, S. H., Rezgui, Y., Kwan, A., 2013. Developing sustainable building assessment scheme for Saudi Arabia: Delphi consultation approach. Renewable and Sustainable Energy Reviews. 27, 43-54.

[41] Dolom, P. C., 2003. Criteria and indicators for assessing the sustainability of a community-based forest management project in the Philippines. Unasylva. 54 (3), 22-26.

[42] Ellison, L., Sayce, S., 2007. Assessing sustainability in the existing commercial property stock: Establishing sustainability criteria relevant for the commercial property investment sector. Property Management. 25 (3), 287-304.

[43] Yang, Y., Li, B., Yao, R., 2010. A method of identifying and weighting indicators of energy efficiency assessment in Chinese residential building. Energy Policy. 38 (12), 7687-7697.

[44] Chew, M. Y. L., Das, S., 2008. Building grading systems: a review of the state-of-the-art. Architectural Science Review. 51 (1), 3-13.

[45] Dalkey, N. C., Helmer, O., 1963. An experimental application of the Delphi method to the use of experts. Management science. 9 (3), 458-467.

[46] Hallowell, M.R. and Gambatese, J.A., 2010. Qualitative research: Application of the Delphi method to CEM research. Journal of construction engineering and management, 136(1), pp.99107.

[47] Dalkey, N. C., 1972. The Delphi method: An experimental study of group opinion. In: Dalkey NC, Rourke DL, Lewis R, Snyder D, editors. Studies in the quality of life: Delphi and decision making, Lexington, MA: Lexington Books, pp.13-54.

[48] Okoli, C., Pawlowski, S. D., 2004. The Delphi method as a research tool: an example, design considerations and applications. Information \& management. 42 (1), 15-29.

[49] Zahoor, H., Chan, A.P., Gao, R. and Utama, W.P., 2017. The factors contributing to construction accidents in Pakistan: their prioritization using the Delphi technique. Engineering, construction and architectural management, 24(3), pp.463-485.

[50] Chan, A.P., Wong, F.K., Hon, C.K., Ali Javed, A. and Lyu, S., 2017. Construction safety and health problems of ethnic minority workers in Hong Kong. Engineering, Construction and Architectural Management, 24(6), pp.901-919.

[51] Vidal, L.A., Marle, F. and Bocquet, J.C., 2011. Using a Delphi process and the Analytic Hierarchy Process (AHP) to evaluate the complexity of projects. Expert systems with applications, 38(5), pp.5388-5405.

[52] Chan, A.P., Yung, E.H., Lam, P.T., Tam, C.M. and Cheung, S.O., 2001. Application of Delphi method in selection of procurement systems for construction projects. Construction Management \& Economics, 19(7), pp.699-718.

[53] Li, H., Zhang, X., Ng, S.T. and Skitmore, M., 2018. Quantifying stakeholder influence in decision/evaluations relating to sustainable construction in China-A Delphi approach. Journal of Cleaner Production, 173, pp.160-170.

[54] Ameyaw, E.E., Hu, Y., Shan, M., Chan, A.P. and Le, Y., 2016. Application of Delphi method in 
construction engineering and management research: a quantitative perspective. Journal of Civil Engineering and Management, 22(8), pp.991-1000.

[55] Paliwoda, S. J., 1983. Predicting the future using Delphi. Management Decision. 21 (1), 31-38.

[56] Delbecq, A. L., Van de Ven, A. H., Gustafson, D. H., 1975. Group techniques for program planning, Glenview. IL: Scott, Foresman, and Co.

[57] Ziglio, E., 1996. The Delphi Method and its Contribution to Decision-Making. In: Alder M, Ziglio E, editors. Gazing into the Oracle, The Delphi Method and its Application to Social Policy and Public Health. London: Jessica Kingsley Publishes, pp. 3-33.

[58] Hsu, C. C., Sandford, B. A., 2007. The Delphi technique: making sense of consensus. Practical assessment, research \& evaluation. 12 (10), 1-8.

[59] Kermanshachi, S., Dao, B., Shane, J. and Anderson, S., 2016. Project Complexity Indicators and Management Strategies-A Delphi Study. Procedia Engineering, 145, pp.587-594.

[60] Powell, C., 2003. The Delphi technique: myths and realities. Journal of advanced nursing. 41 (4), 376-382.

[61] Loo, R., 2002. The Delphi method: a powerful tool for strategic management. Policing: An International Journal of Police Strategies \& Management. 25 (4), 762-769.

[62] Oh, K. H., 1974. Forecasting through hierarchical Delphi. The Ohio State University.

[63] Pill, J., 1971. The Delphi method: substance, context, a critique and an annotated bibliography. Socio-Economic Planning Sciences. 5 (1), 57-71.

[64] Thangaratinam, S., Redman, C. W. E., 2005. The Delphi technique. The obstetrician \& gynaecologist. 7 (2), 120-125.

[65] Custer, R. L., Scarcella, J. A., Stewart, B. R., 1999. The modified Delphi technique-A rotational modification. Journal of Career and Technical Education. 15 (2), 1-10.

[66] Day, J., Bobeva, M., 2005. A generic toolkit for the successful management of Delphi studies. The Electronic Journal of Business Research Methodology. 3 (2), 103-116.

[67] Garg, R., Rahman, Z., Qureshi, M. N., Kumar, I., 2012. Identifying and ranking critical success factors of customer experience in banks: An analytic hierarchy process (AHP) approach. Journal of Modelling in management. 7 (2), 201-220.

[68] Shad, R., Khorrami, M. and Ghaemi, M., 2017. Developing an Iranian green building assessment tool using decision making methods and geographical information system: Case study in Mashhad city. Renewable and Sustainable Energy Reviews, 67, 324-340.

[69] The Straits Times, 2015. Malaysia closes schools as Indonesia smoke haze worsens. Retrieved from http://www.straitstimes.com/asia/se-asia/malaysia-closes-schools-as-indonesia-smoke-hazeworsens (accessed 01.03.16).

[70] Astro Awani, 2015. Water restructuring deal: Will Selangor water crisis come to an end? Retrieved from http://english.astroawani.com/malaysia-news/water-restructuring-deal-willselangor-water-crisis-come-end-72747 (accessed 01.03.16).

[71] Bernama, 2014. Malaysians must stop wasting water. Retrieved from http://english.astroawani.com/malaysia-news/malaysians-must-stop-wasting-water-34654 (accessed 01.03.16).

[72] Kong, Y. Y., Bahrun, N. A., Yew, K., 2010.A study on the urban flooding. Academic Report.

[73] The Star, 2015. Chaos is Klang Valley. Retrieved from http://wildsingaporenews.blogspot.my /2015/11/malaysia-flash-floods-in-johor-baru-and.html\#.VtaWp0cZzNI (accessed 01.03.16).

[74] Shaaban, A. J., 2015. Averting flash floods via rainwater harvesting. Retrieved from http://www.themalaysiantimes.com.my/averting-flash-floods-via-rainwater-harvesting/ (accessed 01.03.16).

[75] Kang, H., Lee, Y. and Kim, S., 2016. Sustainable building assessment tool for project decision makers and its development process. Environmental Impact Assessment Review, 58, 34-47.

European Commission, 2012. Directive 2012/27/EU of the European Parliament and of the Council of 25 October 2012 on energy efficiency, 315 C.F.R. 
Malmqvist, T., Glaumann, M., Svenfelt, Å., Carlson, P. O., Erlandsson, M., Andersson, J., ... \& Malmström, T. G. (2011). A Swedish environmental rating tool for buildings. Energy, 36(4), 1893-1899.

Banani, R., Vahdati, M. M., Shahrestani, M., \& Clements-Croome, D. (2016). The development of building assessment criteria framework for sustainable non-residential buildings in Saudi Arabia. Sustainable Cities and Society, 26, 289-305.

Kang, H. J. (2015). Development of a systematic model for an assessment tool for sustainable buildings based on a structural framework. Energy and Buildings, 104, 287-301.

Diversity of climates

The factors of climate diversity should be taken into account. Hence, various indicate sets for different climate zones should be established. 